\title{
Technical Basis for DOE Standard 3013 Equivalency Supporting Reduced Temperature Stabilization of Oxalate-Derived Plutonium Oxide Produced by the HB-Line Facility at Savannah River Site
}

J. M. Duffey

R. R. Livingston

J. M. Berg

D. K. Veirs

June 29, 2012 
SRNL-STI-2012-00256

Revision 0

\section{DISCLAIMER}

This work was prepared under an agreement with and funded by the U.S. Government. Neither the U.S. Government or its employees, nor any of its contractors, subcontractors or their employees, makes any express or implied:

1. warranty or assumes any legal liability for the accuracy, completeness, or for the use or results of such use of any information, product, or process disclosed; or

2. representation that such use or results of such use would not infringe privately owned rights; or

3. endorsement or recommendation of any specifically identified commercial product, process, or service.

Any views and opinions of authors expressed in this work do not necessarily state or reflect those of the United States Government, or its contractors, or subcontractors.

\section{Printed in the United States of America}

Prepared for

U.S. Department of Energy 
Keywords: Oxalate, plutonium oxide, stabilization, 3013

Standard

Retention: Permanent

\section{Technical Basis for DOE Standard 3013 Equivalency Supporting Reduced Temperature Stabilization of Oxalate-Derived Plutonium Oxide Produced by the HB-Line Facility at Savannah River Site}

J. M. Duffey

R. R. Livingston

J. M. Berg

D. K. Veirs

June 29, 2012

Savannah River National Laboratory

Savannah River Nuclear Solutions, LLC

Aiken, SC 29808

Prepared for the U.S. Department of Energy under contract number DE-AC09-08SR22470. 


\section{REVIEWS AND APPROVALS}

AUTHORS:

\begin{tabular}{ll}
\hline J. M. Duffey, SRNL Date & DR
\end{tabular}

R. R. Livingston, SRNS

Date

J. M. Berg, LANL

Date

D. K. Veirs, LANL

Date

TECHNICAL REVIEW:

T. S. Rudisill, Separations and Actinide Science Programs

Date

S. A. Jones, Pacific Northwest National Laboratory

Date

APPROVAL:

S. D. Fink, Manager

Date

Separations and Actinide Science Programs

S. L. Marra, Manager

Date

Environmental \& Chemical Process Technology Research Programs

K. P. Burrows, Manager

Date

HB-Line Engineering 
SRNL-STI-2012-00256

Revision 0

\section{EXECUTIVE SUMMARY}

The HB-Line (HBL) facility at the Savannah River Site (SRS) is designed to produce high-purity plutonium dioxide $\left(\mathrm{PuO}_{2}\right)$ which is suitable for future use in production of Mixed Oxide (MOX) fuel. The MOX Fuel Fabrication Facility (MFFF) requires $\mathrm{PuO}_{2}$ feed to be packaged per the U.S. Department of Energy (DOE) Standard 3013 (DOE-STD-3013) to comply with the facility's safety basis. The stabilization conditions imposed by DOE-STD-3013 for $\mathrm{PuO}_{2}$ (i.e., $950{ }^{\circ} \mathrm{C}$ for 2 hours) preclude use of the $\mathrm{HBL} \mathrm{PuO}_{2}$ in direct fuel fabrication and reduce the value of the $\mathrm{HBL}$ product as MFFF feedstock. Consequently, HBL initiated a technical evaluation to define acceptable operating conditions for production of high-purity $\mathrm{PuO}_{2}$ that fulfills the DOE-STD3013 criteria for safe storage. The purpose of this document is to demonstrate that within the defined operating conditions, the HBL process will be equivalent for meeting the requirements of the DOE-STD-3013 stabilization process for plutonium-bearing materials from the DOE complex.

The proposed 3013 equivalency reduces the prescribed stabilization temperature for high-purity $\mathrm{PuO}_{2}$ from oxalate precipitation processes from $950{ }^{\circ} \mathrm{C}$ to $640{ }^{\circ} \mathrm{C}$ and places a limit of $60 \%$ on the relative humidity ( $\mathrm{RH})$ at the lowest material temperature. The equivalency is limited to material produced using the HBL established flow sheet, for example, nitric acid anion exchange and $\mathrm{Pu}(\mathrm{IV})$ direct strike oxalate precipitation with stabilization at a minimum temperature of $640{ }^{\circ} \mathrm{C}$ for four hours (h). The product purity must meet the MFFF acceptance criteria of 23,600 $\mu \mathrm{g} / \mathrm{g} \mathrm{Pu}$ (i.e., $2.1 \mathrm{wt} \%$ ) total impurities and chloride content less than $250 \mu \mathrm{g} / \mathrm{g}$ of Pu. All other stabilization and packaging criteria identified by DOE-STD-3013-2012 or earlier revisions of the standard apply. Based on the evaluation of test data discussed in this document, the expert judgment of the authors supports packaging the HBL product under a 3013 equivalency.

Under the defined process conditions and associated material specifications, the high-purity $\mathrm{PuO}_{2}$ produced in HBL presents no unique safety concerns for packaging or storage in the 3013 required configuration. The $\mathrm{PuO}_{2}$ produced using the $\mathrm{HBL}$ flow sheet conditions will have a higher specific surface area (SSA) than $\mathrm{PuO}_{2}$ stabilized at $950{ }^{\circ} \mathrm{C}$ and, consequently, under identical conditions will adsorb more water from the atmosphere. The greatest challenge to HBL operators will be controlling moisture content below $0.5 \mathrm{wt} \%$. However, even at the $0.5 \mathrm{wt} \%$ moisture limit, the maximum acceptable pressure of a stoichiometric mixture of hydrogen and oxygen in the 3013 container is greater than the maximum possible pressure for the HBL $\mathrm{PuO}_{2}$ product. 


\section{TABLE OF CONTENTS}

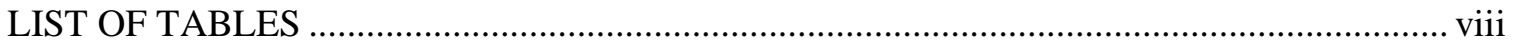

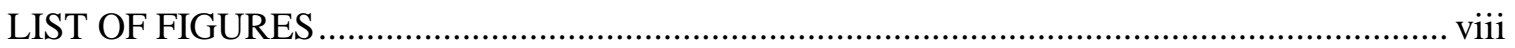

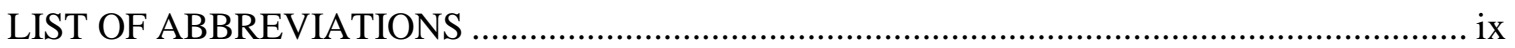

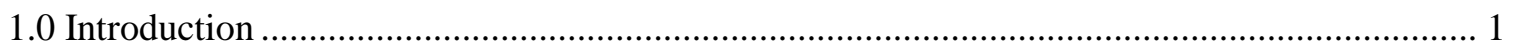

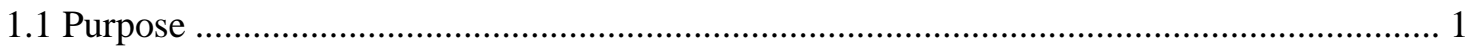

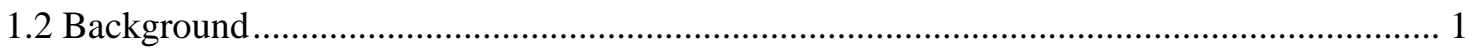

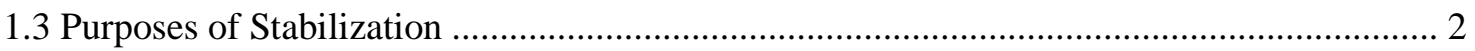

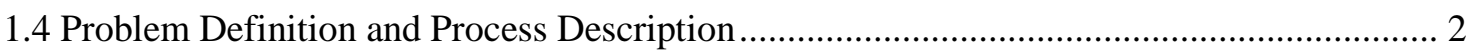

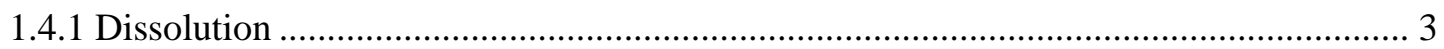

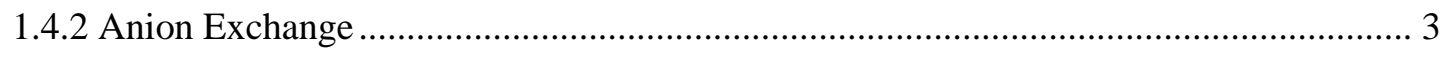

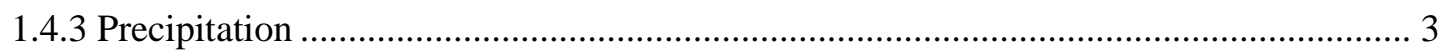

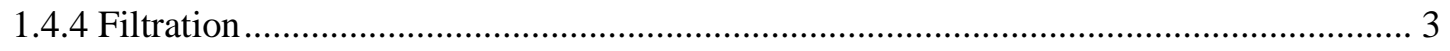

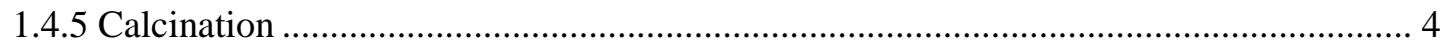

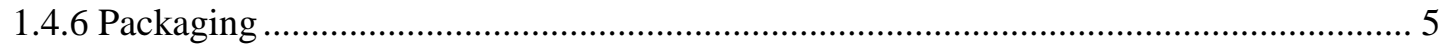

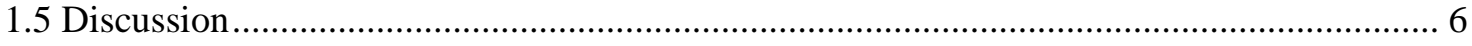

1.6 Equivalency of Alternative Processing Pathway ............................................................. 7

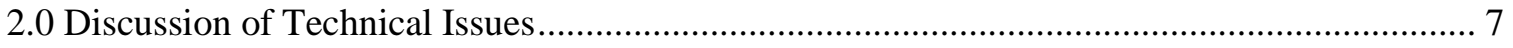

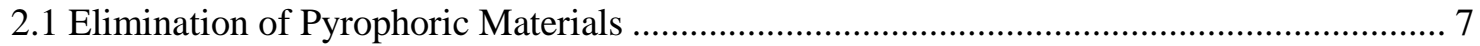

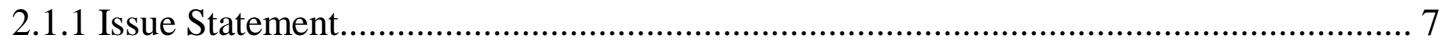

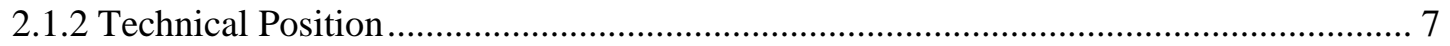

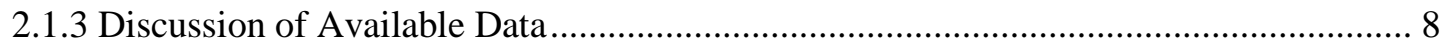

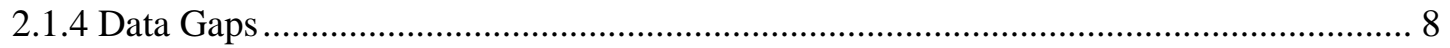

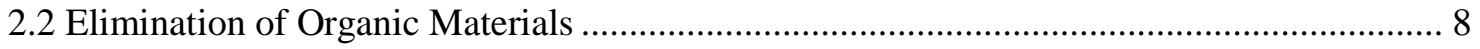

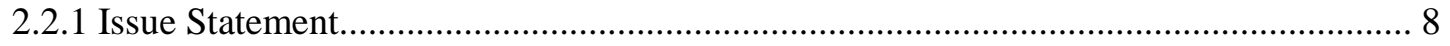

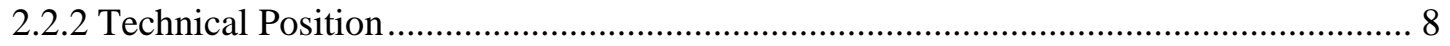

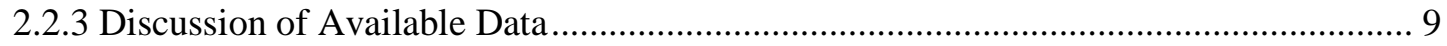

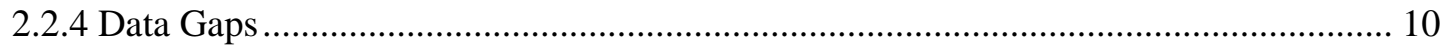

2.3 Reduction of Content of Water and Other Water-Producing Species.................................. 10

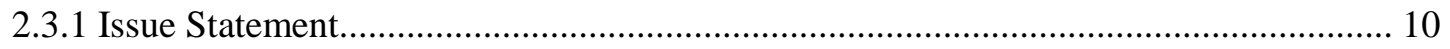

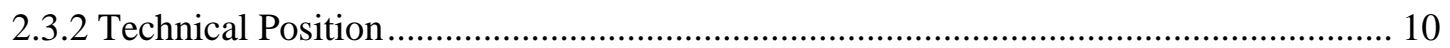

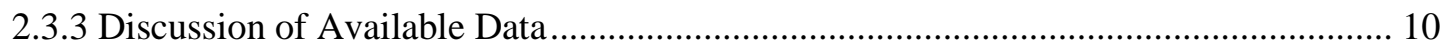

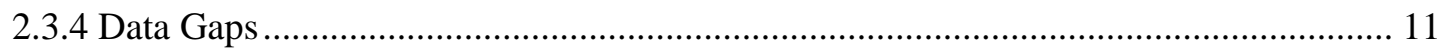

2.4 Minimization of Potential for Adsorption or Readsorption of Water ................................. 11 


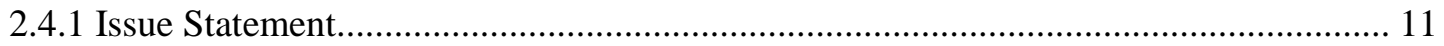

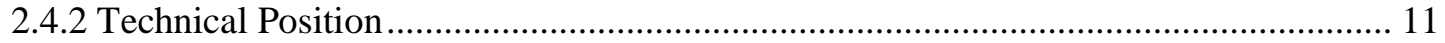

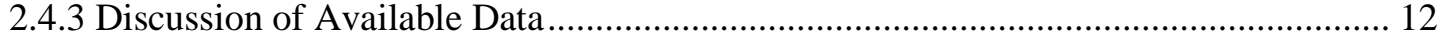

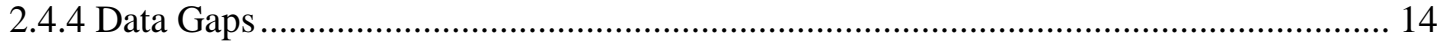

2.5 Stabilization of Potential Gas-Producing Constituents ....................................................... 14

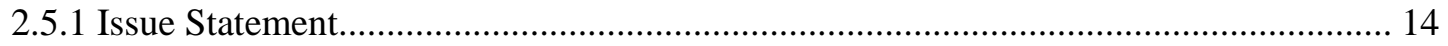

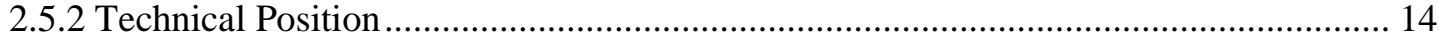

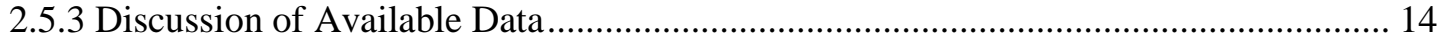

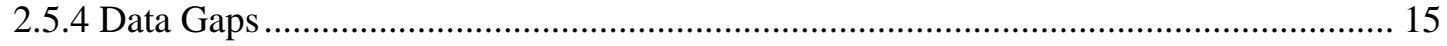

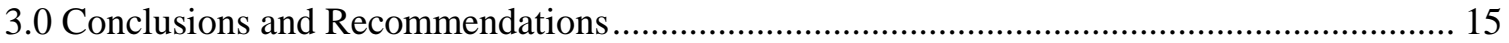

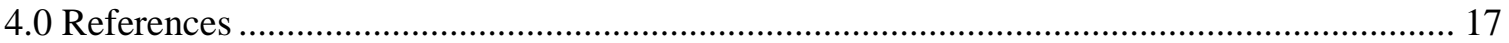

Appendix A. Chemical Impurity Limits for HB-Line Feed to MFFF ......................................... A-1 


\section{LIST OF TABLES}

Table 1. Calculated maximum pressures in $\mathrm{kPa}$ as a function of the mass of oxide and the $\mathrm{RH}$ the

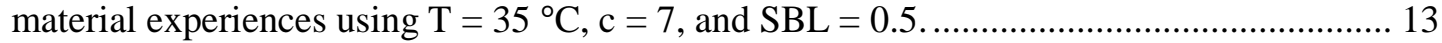

\section{LIST OF FIGURES}

Figure 1. Block diagram of the HBL Phase II process............................................................ 2

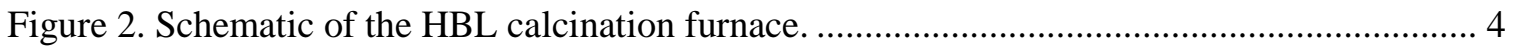

Figure 3. Calculated maximum pressure as a function of equilibrium $\mathrm{RH}$ for $5000 \mathrm{~g}$ of $\mathrm{PuO}_{2} \ldots 13$ 


\section{LIST OF ABBREVIATIONS}

\begin{tabular}{|c|c|}
\hline $\mathrm{Al}\left(\mathrm{NO}_{3}\right)_{3}$ & aluminum nitrate \\
\hline BV & bed volume \\
\hline c & $\begin{array}{l}\mathrm{C}=\mathrm{e}^{\Delta \mathrm{H} / \mathrm{RT}} \text {, where } \Delta \mathrm{H} \text { is the excess heat of adsorption compared to the heat } \\
\text { of condensation of the liquid }\end{array}$ \\
\hline${ }^{\circ} \mathrm{C}$ & degrees Celsius \\
\hline $\mathrm{CO}_{3}{ }^{2-}$ & carbonate ion \\
\hline $\mathrm{C}_{2} \mathrm{O}_{4}{ }^{2-}$ & oxalate ion \\
\hline $\mathrm{DE}$ & Destructive Examination \\
\hline DOE & U.S. Department of Energy \\
\hline $\mathrm{F}^{-}$ & fluoride ion \\
\hline g & gram \\
\hline h & hour \\
\hline HBL & HB-Line \\
\hline $\mathrm{HNO}_{3}$ & nitric acid \\
\hline ISSC & Interim Safe Storage Criteria \\
\hline KF & potassium fluoride \\
\hline $\mathrm{kg}$ & kilogram \\
\hline $\mathrm{L}$ & liter \\
\hline LANL & Los Alamos National Laboratory \\
\hline LOI & mass loss on ignition \\
\hline LTA & Lead Test Assembly \\
\hline $\mathrm{m}$ & meter \\
\hline M & molar \\
\hline MFFF & Mixed Oxide Fuel Fabrication Facility \\
\hline $\min$ & minute \\
\hline MIS & Materials Identification and Surveillance \\
\hline MOX & Mixed Oxide \\
\hline NIST & National Institute of Standards and Technology \\
\hline $\mathrm{NO}_{3}^{-}$ & nitrate ion \\
\hline $\mathrm{PuO}_{2}$ & plutonium dioxide \\
\hline $\mathrm{RH}$ & relative humidity \\
\hline rpm & revolutions per minute \\
\hline SBL & strongly bound layer \\
\hline $\operatorname{scfm}$ & standard cubic feet per minute \\
\hline
\end{tabular}




$\begin{array}{ll}\mathrm{SO}_{4}{ }^{2-} & \text { sulfate ion } \\ \text { SRNL } & \text { Savannah River National Laboratory } \\ \text { SRS } & \text { Savannah River Site } \\ \text { SSA } & \text { specific surface area } \\ \text { TGA } & \text { thermogravimetric analysis } \\ \text { TGA-MS } & \text { thermogravimetric analysis - mass spectrometry } \\ \text { wt \% } & \text { weight percent }\end{array}$




\subsection{Introduction}

\subsection{Purpose}

This report documents the technical basis to support a determination that stabilizing high-purity plutonium dioxide $\left(\mathrm{PuO}_{2}\right)$ derived from direct strike plutonium(IV) oxalate precipitation at the Savannah River Site (SRS) HB-Line (HBL) facility at no less than $640{ }^{\circ} \mathrm{C}$ for a minimum of four hours (h) in an oxidizing atmosphere is equivalent to stabilizing at $950{ }^{\circ} \mathrm{C}$ as regards meeting the objectives of stabilization defined for U.S. Department of Energy (DOE) Standard 3013 (DOE-STD-3013) (DOE, 2012) if the material is handled in a way to prevent excessive adsorption of water. Establishing technical equivalency will enable HBL to operate at the lower temperature to produce and package $\mathrm{PuO}_{2}$ for use by the Mixed Oxide (MOX) Fuel Fabrication Facility (MFFF).

\subsection{Background}

HBL plans to produce high-purity $\mathrm{PuO}_{2}$ using conditions appropriate for manufacture of MOX fuel (Christopher, 2011). The HBL mission requires packaging the $\mathrm{PuO}_{2}$ in 3013 containers for receipt and storage by the MFFF. Reducing the required calcination temperature of the HBL product is of significant benefit to MFFF and is required for MFFF feed stock that is used in direct fabrication of MOX fuel assemblies; however, the 3013 packaging for incoming material is required to meet the MFFF safety basis and support automated handling of the $\mathrm{PuO}_{2}$ feedstock. Consequently, HBL requested assistance from the Savannah River National Laboratory (SRNL) and Los Alamos National Laboratory (LANL) to develop the technical basis to demonstrate equivalency of lower-temperature stabilization for HBL oxide from oxalate precipitation.

The current HBL facilities were built in the mid-1980s and, along with other DOE-EM missions, have been used for production of Pu-238, Pu-239 and Np-237 oxide products. The process experience associated with these past production campaigns demonstrates the facility's capability to meet rigorous production requirements.

As HBL begins production of $\mathrm{PuO}_{2}$ under the proposed equivalency, samples of the HBL product will be placed into the MIS Shelf Life Program to evaluate material performance under 3013 storage conditions. The results of the MIS evaluation will support closure of data gaps identified during preparation of this document. Packaging of the $\mathrm{HBL} \mathrm{PuO}_{2}$ in 3013 containers is expected to be deferred for 18 to 48 months as HBL establishes the capability for welding 3013 inner cans.

After production of the HBL product, Interim Safe Storage Criteria (ISSC) will be utilized for packaging and storage of the $\mathrm{PuO}_{2}$ in the SRS K-Area vault (Hackney, 2011). The analytical requirements and process controls necessary for ISSC are not addressed in this evaluation. However, once the $\mathrm{PuO}_{2}$ is returned to HBL for 3013 packaging, the moisture limit and other 3013 packaging criteria will be verified to demonstrate conformance with the 3013 Standard. The preliminary design for the HBL inner 3013 can welder includes requirements for a dry nitrogen atmosphere (i.e., $<1 \% \mathrm{O}_{2},<5 \% \mathrm{RH}$ ) for packaging.

Prior to packaging $\mathrm{PuO}_{2}$ produced under this equivalency, an in-depth review of HBL procedures and operational controls will be completed following the detailed " 20 Points" process required for shipment of 3013 products to SRS (Gupta et al., 2000). As part of this review, HBL will document the process used for collecting and analyzing moisture samples; controls that are required for deferred packaging; measurement uncertainty associated with furnace temperature, product mass, RH, product purity, etc. 


\subsection{Purposes of Stabilization}

The objectives for stabilization of plutonium-bearing oxides are listed in Appendix A of the DOE-STD-3013 (DOE 2012), Section A.6.1.2.1, p. 20, as follows:

- eliminate reactive materials such as finely divided metal or sub-stoichiometric plutonium oxides;

- eliminate organic materials;

- reduce water content to less than $0.5 \mathrm{wt} \%$ and similarly reduce equivalent quantities of species such as hydrates and hydroxides that might produce water;

- minimize potential for water re-adsorption above $0.5 \mathrm{wt} \%$ threshold; and

- stabilize any other potential gas-producing constituents.

The first objective is intended to avoid energetic events, for example, when storage containers are opened. The other four objectives are all intended to minimize the potential for pressurization of the container due to chemical, radiolytic, or thermal degradation of impurities, especially water. To achieve these objectives with high confidence for a broad range of materials, the standard specifies that oxide material will be placed in a continuously oxidizing atmosphere at a material temperature of at least $950^{\circ} \mathrm{C}$ for a minimum of two hours.

\subsection{Problem Definition and Process Description}

The reduced stabilization temperature equivalency will be demonstrated for high-purity $\mathrm{PuO}_{2}$ containing less than $2.1 \mathrm{wt} \%$ total impurities (McAlhany, 2012). The $\mathrm{PuO}_{2}$ will be produced in the SRS H-Canyon and HBL facilities for eventual use as feed into the MFFF process. The chemical impurity limits for the oxide product are listed in Appendix A. The combined HCanyon/HBL flow sheet, or process (Garrison and Clifton, 2012; Smith, 2012) is summarized below. This flow sheet is similar to the flow sheet used by LANL to produce approximately 330 $\mathrm{kg}$ of $\mathrm{PuO}_{2}$ for MOX Lead Test Assemblies (LTA) during the time frame of 2001 - 2008 (Alwin, 2007; Bluhm, 2005). Figure 1 is a process diagram that shows the basic flow of materials described in the following paragraphs.

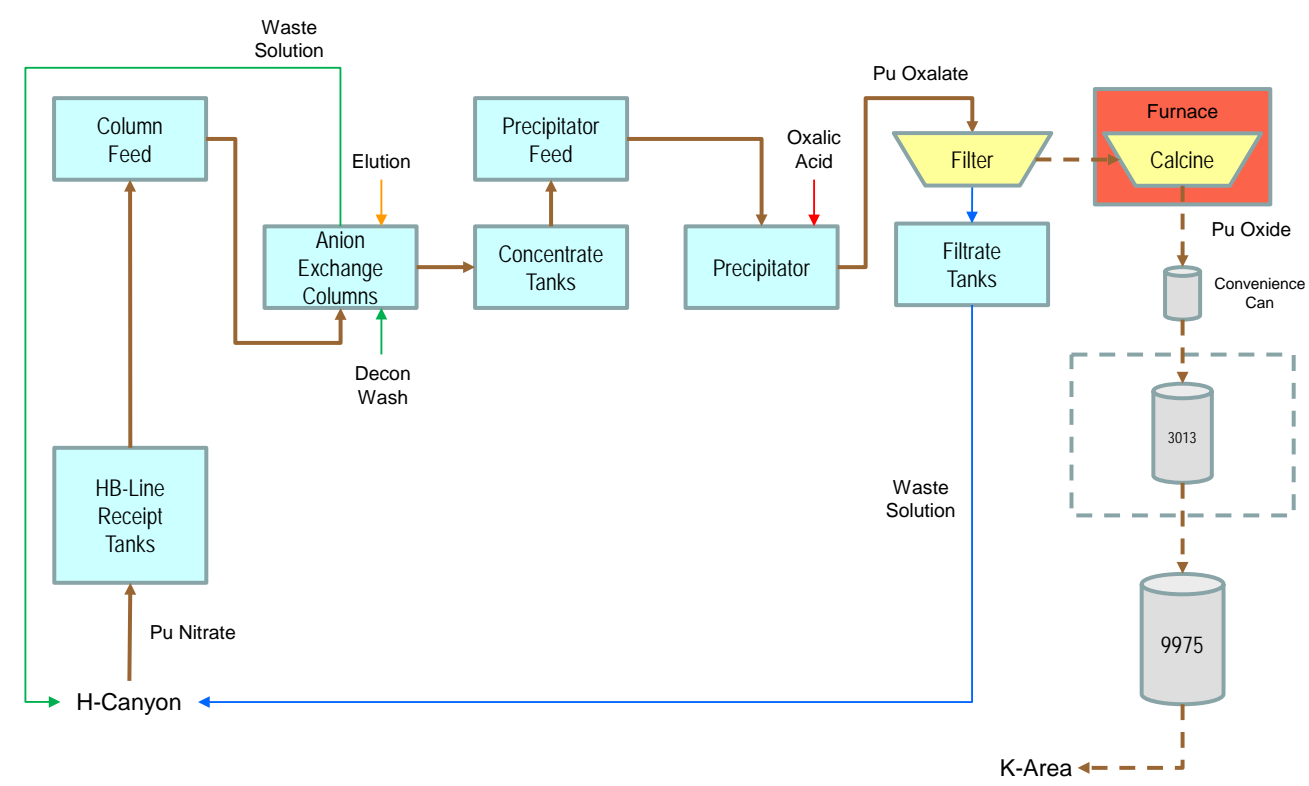

Figure 1. Block diagram of the HBL Phase II process. 


\subsubsection{Dissolution}

$\mathrm{H}$-Canyon will receive $\mathrm{Pu}$ metal ${ }^{1}$ packaged in dissolvable carbon-steel cans that are sealed to minimize formation of $\mathrm{Pu}$ oxide and packaged in nylon bags for contamination control. The $\mathrm{Pu}$ metal and associated packaging is dissolved by placing in a boiling solution containing nominally $10 \mathrm{M}$ nitric acid $\left(\mathrm{HNO}_{3}\right)$, with about $0.1 \mathrm{M}$ potassium fluoride (KF), for 24-48 hours (h). Gadolinium or boron may be added to the dissolver as a neutron poison (Garrison and Clifton, 2012). After each dissolution cycle, the dissolver solution is expected to contain approximately $1-2 \mathrm{~g} / \mathrm{L} \mathrm{Fe}$, and other minor impurities. Upon cooling, aluminum nitrate $\left(\mathrm{Al}\left(\mathrm{NO}_{3}\right)_{3}\right)$ solution will be added to complex fluoride ion ( $\mathrm{F}^{-}$) prior to transferring solutions to HBL. The Pu concentration in the HBL feed will depend on a number of variables associated with criticality safety controls but is expected to range from 2 to $4 \mathrm{~g} / \mathrm{L}$. The impurities associated with H-Canyon dissolution, along with those initially in the Pu metal, are subsequently removed by the HBL anion exchange and precipitation operations.

\subsubsection{Anion Exchange}

HBL will utilize two anion exchange resin columns in parallel to achieve the desired throughput. None of the column feed or column operation steps are anticipated to introduce additional process impurities. Upon receipt in $\mathrm{HBL}$, the column feed solution will be analyzed to verify $\mathrm{HNO}_{3}$ concentration prior to loading the anion columns. No valence adjustment step is required based on prior experience for short term storage of low concentration $\mathrm{Pu}$ solutions in nitric acid solutions appropriate for anion feed. The columns are conditioned with nominally $8 \mathrm{M} \mathrm{HNO}_{3}$, loaded with the feed solution from H-Canyon, then washed sufficiently to remove contaminants to meet specifications for the MOX product (Kyser and King, 2012). The Pu feed solutions are passed through a $10-\mu \mathrm{m}$ filter (HBL, 2007) prior to loading the anion columns to prevent any solids or other particulate matter from interfering with process operations. Once washed, the column will be eluted with nominally $0.35 \mathrm{M} \mathrm{HNO}_{3}$. The combined product solution from both columns is expected to contain greater than $40 \mathrm{~g} / \mathrm{L} \mathrm{Pu}$ in low molarity $\mathrm{HNO}_{3}$ (Smith, 2012; Garrison and Clifton, 2012). Laboratory analysis is used to validate removal of impurities following anion exchange during process start-up and periodically as needed to support the HBL process control strategy.

\subsubsection{Precipitation}

The anion exchange product solution will be fed to the HBL precipitator, and $\mathrm{Pu}$ will be precipitated by the addition of nominally $0.95 \mathrm{M}$ oxalic acid solution (i.e., direct strike precipitation). The precipitator solution temperature will be maintained at approximately $50 \pm$ $5{ }^{\circ} \mathrm{C}$ during precipitation and allowed to digest for $5 \mathrm{~min}$ or longer prior to filtration. The total amount of oxalic acid added will be equal to two moles of oxalic acid per mole of Pu plus enough to achieve approximately 0.1 M excess oxalic acid (Smith, 2012).

\subsubsection{Filtration}

The resulting slurry will be transferred to the HBL filtrate tank with the precipitate collected on a filter boat with a nominally $10-\mu \mathrm{m}$ stainless steel screen. During the filtration operation, a wash solution consisting of low molarity $\mathrm{HNO}_{3}$ and oxalic acid will be utilized to flush the precipitator vessel and wash the plutonium oxalate filtrate to remove additional soluble impurities. When filtration is complete, the filter boat will be lowered and air dried for approximately 60 min by

\footnotetext{
${ }^{1}$ Although the starting material for the current HBL flow sheet is Pu metal, the arguments for 3013 equivalency would also apply to $\mathrm{PuO}_{2}$ produced using the same flow sheet but starting with oxide as long as the final product meets the same purity specifications and moisture content at packaging.
} 
pulling air through the filter cake to remove excess moisture prior to calcination (Smith, 2012). Quality of the reagents and process water used for HBL operations are monitored to avoid addition of any undesired contaminates.

\subsubsection{Calcination}

In HBL, the filter boat also serves as the calcination furnace boat. To initiate the calcination step, the filter boat is raised into the furnace and heated to a bed temperature of $640{ }^{\circ} \mathrm{C}$ or greater for a minimum of $4 \mathrm{~h}$ while pulling air through the filter cake at a minimum of $0.5 \mathrm{scfm}$ as measured by a downstream rotameter. Figure 2 illustrates the furnace layout and identifies the basic components. The centerline of the product bed is expected to be the coolest point in the furnace and is used to determine calcination temperature. This thermocouple is calibrated with traceability to the National Institute of Standards and Technology (NIST). The furnace temperature will be controlled to achieve an indicated product bed temperature of nominally $650^{\circ} \mathrm{C}$; however, with associated uncertainty in this temperature reading, the actual product temperature will be no less than $640{ }^{\circ} \mathrm{C}$ as proposed for the 3013 equivalency. Following calcination, the oxide product will be cooled to less than $100{ }^{\circ} \mathrm{C}$ by pulling glove box air through the furnace shell before lowering the filter boat from the furnace. The process steps followed during product cooling will minimize exposure of the oxide product to the glove box atmosphere and transfer the product to a sealed container as soon as reasonably possible upon cooling to less than $100{ }^{\circ} \mathrm{C}$. This step is noted as an important aspect of moisture control on the $3013 \mathrm{PuO}_{2}$ product.

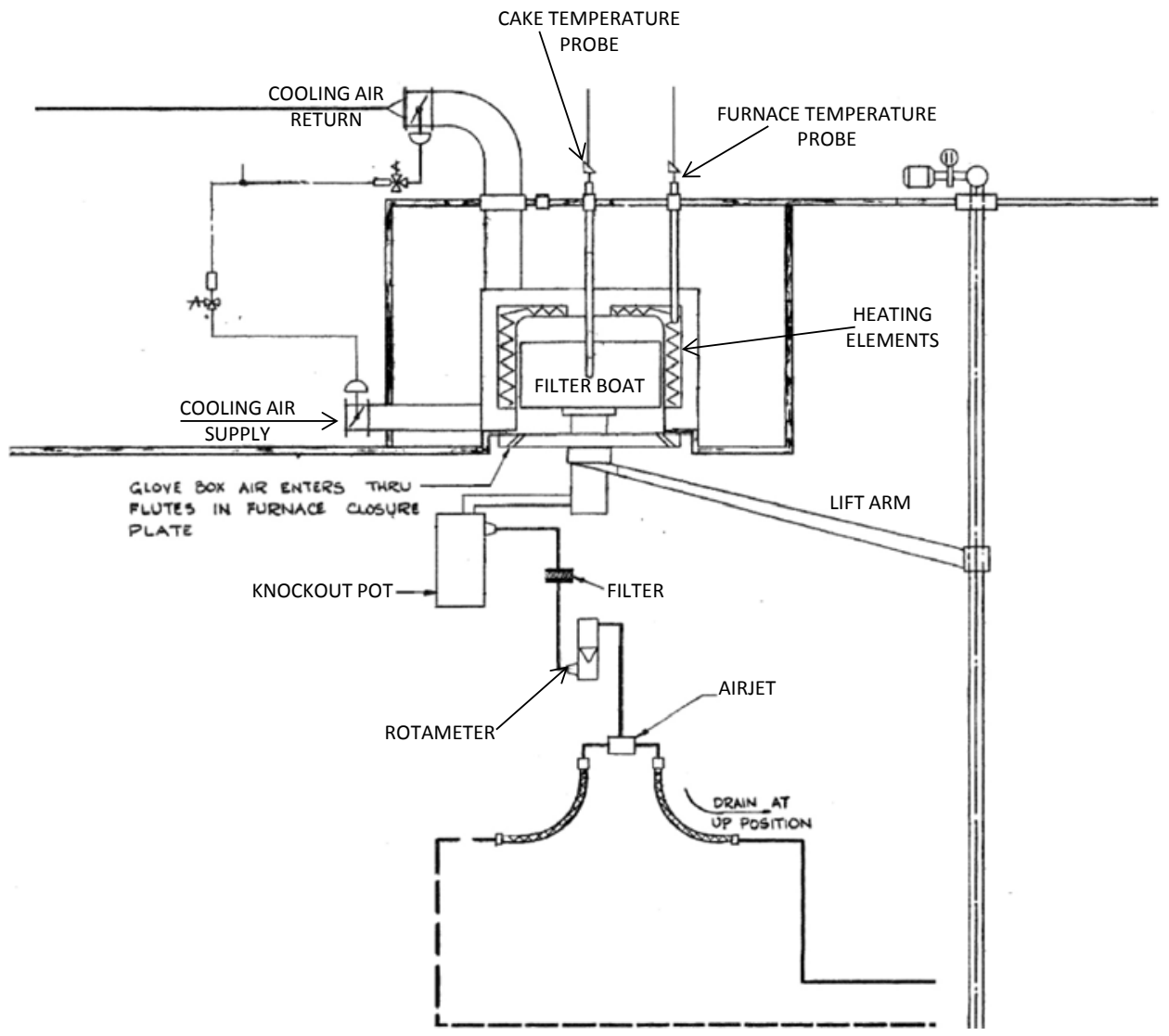

Figure 2. Schematic of the HBL calcination furnace. 
Once calcined, the $\mathrm{PuO}_{2}$ product will be controlled to maintain the $\mathrm{RH}$ at the product surface to less than 60\% (including measurement uncertainty). The RH is monitored by two independent probes in the processing area; hand-held RH probes may also be used. The RH exposure at the product surface will be determined based on the highest measured $\mathrm{RH}$ value and the material temperature. Limiting moisture adsorption is dependent on a combination of multiple process controls beginning with facility HVAC. Additional controls include maintaining product temperature greater than ambient process temperature (e.g., keeping product in the furnace at elevated temperature, transferring product to sealed containers while still warm, evaluating $\mathrm{PuO}_{2}$ self-heating under various process and package configurations, etc.) and using sealed containers to limit exposure to glove box atmosphere. The benefits of maintaining product temperature above ambient temperature are discussed in Section 2.4.3. If the $\mathrm{RH}$ at the product surface is not maintained below $60 \%$, the $\mathrm{PuO}_{2}$ product will be reconditioned by heating to $640{ }^{\circ} \mathrm{C}$ or greater.

\subsubsection{Packaging}

Each batch of $\mathrm{PuO}_{2}$ will be transferred after calcination from the filter boat to an interim storage container or product container depending on the batch size. If needed, the interim storage container will be used to combine and store $\mathrm{PuO}_{2}$ from multiple furnace runs prior to filling the product container or convenience can that is used for storage of $\mathrm{PuO}_{2}$ prior to packaging in the 3013 inner can. HBL will begin operations using a deferred packaging arrangement that allows the $\mathrm{PuO}_{2}$ product to be stored in a Type $\mathrm{B}$ package ${ }^{2}$ prior to start-up of the 3013 inner canning system. The specific details of this packaging have not been specified at this time; however, the following general principles apply to this and future operations. Moisture controls for the $\mathrm{PuO}_{2}$ product will be instituted to limit moisture uptake to the greatest extent possible. These controls focus on monitoring glove box RH conditions, minimizing the time product is exposed to the glove box atmosphere, and establishing sampling and moisture analysis methods that provide a reliable yet conservative estimate of product moisture content.

For example, to minimize moisture adsorption during storage in the glove box line, the interim storage container and product containers may be placed into a second container with an elastomeric seal to limit exposure to ambient RH conditions. Once the product container has been filled and is ready for sampling, a core sampling tool will be used to collect a sample for moisture analysis and load into a sample vial with an O-ring seal. The core sample will be pulled from as near as practical to the container wall (i.e., coolest point in the container) and from the full bed depth of oxide in the product can to represent the bulk material. The sample vial will remain sealed until the thermogravimetric analysis (TGA) or TGA-mass spectrometry (TGA-MS) moisture analysis is performed. ${ }^{3}$ The product container mass will be recorded immediately after sampling to allow tracking of any additional moisture adsorption of the oxide based on container mass. This sample moisture measurement results plus any measured increase in the product container mass will be summed to estimate the total product moisture content. This calculated moisture content along with measurement uncertainty will be considered when comparing to the 3013 standard $0.5 \mathrm{wt} \%$ moisture limit.

Details of moisture analysis and deferred packaging will be presented as part of the HBL " 20 Points" document used to demonstrate compliance with the 3013 Standard prior to packaging in a

\footnotetext{
${ }^{2}$ If the product containers are required to be inerted (e.g., to reduce oxygen content), an "inert" gas such as nitrogen, helium, or argon (rather than, for example, carbon dioxide) will be used to avoid interactions with the product material.

${ }^{3}$ Note that TGA/TGA-MS procedures authorized for 3013 moisture analysis (or equivalent) will be used for sample analysis.
} 
3013 compliant configuration and approved by the appropriate technical authority for 3013 operations.

\subsection{Discussion}

Prior DOE requests for 3013 equivalency were based on a technical evaluation of feed materials and process conditions (e.g., $750{ }^{\circ} \mathrm{C}$ calcination of chloride-bearing oxides) to demonstrate the proposed content would not impact container integrity or storage safety (Boak et al., 2002; Boak et al., 2003). The two processes of concern are corrosion and gas generation. In this case, the proposed content will be high-purity $\mathrm{PuO}_{2}$ with little chlorine (F plus $\mathrm{Cl}<250 \mu \mathrm{g} / \mathrm{g} \mathrm{Pu}$ ). ${ }^{4}$ The $\mathrm{RH}$ within the package can be as high as the packaging $\mathrm{RH}$, which may be as high as $70 \%$. General corrosion, which may occur under these conditions, has been evaluated by the 3013 Standard as not a credible problem [A.6.3.2.6]. The small amount of chlorine will be homogenously distributed throughout the high-purity $\mathrm{PuO}_{2}$ product by the precipitation and calcination process. In order for the chlorine to cause pitting or stress-corrosion cracking, chloride salts must be present that can deliquesce to form liquids. This has not been observed in sealed containers with high-purity $\mathrm{PuO}_{2}$ and less than $0.5 \mathrm{wt} \%$ water by either the SRS Destructive Examination (DE) program or the MIS program. Therefore, this review is primarily focused on the potential for gas generation to impact 3013 container safety. ${ }^{5}$

Because the material will be stabilized at $640{ }^{\circ} \mathrm{C}$ or greater rather than $950{ }^{\circ} \mathrm{C}$, the HBL product is anticipated to have a higher specific surface area (SSA) and potentially higher carbon content than plutonium-bearing oxide materials represented in the MIS Shelf-Life Program. HBL has limited capability to control process glove box RH, and consequently, the higher SSA that results from calcination at lower temperatures poses a challenge to limit moisture re-adsorption.

Limited gas generation data is available for high-purity $\mathrm{PuO}_{2}$ materials produced by calcination of plutonium oxalate at temperatures between $600{ }^{\circ} \mathrm{C}$ and $700{ }^{\circ} \mathrm{C}$ and having relatively high SSAs (i.e., between $5 \mathrm{~m}^{2} / \mathrm{g}$ and $15 \mathrm{~m}^{2} / \mathrm{g}$ ) as expected for the HBL product. Short-term (i.e., $200 \mathrm{~h}$ to $400 \mathrm{~h}$ duration), small-scale gas generation tests were conducted at the Savannah River Technology Center (now SRNL) with $\mathrm{PuO}_{2}$ having either weapons grade or fuel grade isotopic mixtures produced by anion exchange purification, precipitation of plutonium(III) oxalate, and calcination in air at $450{ }^{\circ} \mathrm{C}$ for $4 \mathrm{~h}$ followed by an additional $2 \mathrm{~h}$ at $700{ }^{\circ} \mathrm{C}$ (Livingston and Duffey, 2001; Duffey and Livingston, 2002). These materials had SSAs of approximately $10 \mathrm{~m}^{2} / \mathrm{g}$ (Jurgensen et al., 2005). Both weapons grade and fuel grade $\mathrm{PuO}_{2}$ samples packaged in air with no added moisture (TGA LOI at $950{ }^{\circ} \mathrm{C}$ of $1.0 \mathrm{wt} \%$ and $0.5 \mathrm{wt} \%$, respectively) consumed $\mathrm{O}_{2}$ and generated $\mathrm{H}_{2}$. With approximately 0.3 wt \% added water (which was most likely $>0.5 \mathrm{wt} \%$ total water), the weapons grade samples packaged in air generated $\mathrm{H}_{2}$ at a much faster rate, but still consumed $\mathrm{O}_{2}$; and with about 1.0 wt \% added water these samples generated both $\mathrm{H}_{2}$ and $\mathrm{O}_{2}$. The fuel grade samples with about 0.8 wt \% added water generated both $\mathrm{H}_{2}$ and $\mathrm{O}_{2}$ when packaged in air, $\mathrm{N}_{2}$, or Ar. Therefore, while these short-term tests with high-purity $\mathrm{PuO}_{2}$ having SSA in the range expected for HBL product suggests $\mathrm{O}_{2}$ is not generated for samples packaged with $<0.5$ wt \% moisture packaged in air, they do not preclude $\mathrm{H}_{2}$ plus $\mathrm{O}_{2}$ generation at some longer storage time or when packaged with lower initial $\mathrm{O}_{2}$ content.

The MIS Shelf Life Program evaluated two samples of a high surface area product identified as MISSTD-1 with a SSA of 20-30 $\mathrm{m}^{2} / \mathrm{g}$ (Berg et al., 2012). This material was produced by oxalate

\footnotetext{
${ }^{4}$ Verification that $\mathrm{F}$ plus $\mathrm{Cl}$ levels are $<250 \mu \mathrm{g} / \mathrm{g}$ Pu will be achieved by measurement of samples of the oxide product.

${ }^{5}$ It is critical to the equivalency evaluation that the $\mathrm{HBL}$ production process and $\mathrm{PuO}_{2}$ product be isolated from potential chloride contamination associated with future HBL activities (e.g., 3013 oxide repackaging).
} 
precipitation and calcination at $600{ }^{\circ} \mathrm{C}$ for $6 \mathrm{~h}$. In the small scale container test, this sample most likely contained $0.7-1.0 \mathrm{wt} \%$ moisture and generated a low pressure of $\mathrm{H}_{2}$ and $\mathrm{O}_{2}$. The maximum pressure measured in this test was approximately $100 \mathrm{kPa}$, and the associated gas composition includes about $4 \mathrm{vol} \% \mathrm{H}_{2}$ and $15 \mathrm{vol} \% \mathrm{O}_{2}$. The history of the MISSTD- 1 material indicates extended exposure to the glove box atmosphere and is described as "aged" material to indicate this sample was not freshly calcined prior to loading. This same material when loaded into a large scale container did not generate $\mathrm{H}_{2}$ or $\mathrm{O}_{2}$; however, a significant quantity of $\mathrm{N}_{2}$ was produced during this test. Samples analyzed from the large scale test container of MISSTD-1 indicated a moisture content of $\sim 1 \mathrm{wt} \%$ and $\mathrm{C}$ content also close to $1 \mathrm{wt} \%$. The moisture content, $\mathrm{C}$ content, and duration of air exposure for the MISSTD-1 materials were all greater than allowed for HBL product under the proposed 3013 equivalency. However, due to the relatively high SSA of MISSTD-1, coverage of the oxide surface by adsorbed water may have resulted in fewer monolayer equivalents (ML) of adsorbed water than will be possible for the HBL oxide product. The potential for water adsorption by $\mathrm{PuO}_{2}$ and the implications for gas generation are addressed in section 2.4.

\subsection{Equivalency of Alternative Processing Pathway}

The basis for determining whether an alternative stabilization is equivalent lies in establishing that it is equally effective in meeting the objectives for stabilization listed in DOE-STD-3013. The final objective of stabilization is to ensure the nuclear material can be stored safely for up to 50 years in a specified, sealed, stainless steel container. For the purpose of this document, equivalency means that the proposed lower temperature stabilization process meets the same objectives as the process requirements set forth in the Standard with the goal of ensuring longterm stability in storage. Equivalency does not mean that the material produced using a calcination temperature of $640^{\circ} \mathrm{C}$ has the same material properties, such as SSA, as the material produced at a calcination temperature of $950^{\circ} \mathrm{C}$.

The next section discusses and summarizes the evidence that high-purity $\mathrm{PuO}_{2}$ produced in $\mathrm{HBL}$ and stabilized at $640{ }^{\circ} \mathrm{C}$ or greater instead of $950{ }^{\circ} \mathrm{C}$ will be equivalent to material stabilized in compliance with DOE-STD-3013 for each of the stated purposes of stabilization. It is shown that the material must be handled in a way to prevent excessive adsorption or readsorption of water that occurs because of the higher SSA. Assurance of adequate stabilization will be verified by defining appropriate quality assurance and surveillance measures including moisture measurement.

\subsection{Discussion of Technical Issues}

\subsection{Elimination of Pyrophoric Materials}

\subsubsection{Issue Statement}

The stabilization process is expected to oxidize any residual metal that may be present in the material so there remains little or no hazard from potential pyrophoric reactions to occur if containers are breached in an accident or when they are opened in the future. Stabilization is also expected to oxidize substoichiometric plutonium oxide to $\mathrm{PuO}_{2}$. For the $\mathrm{HBL}$ oxide product, the question is how stabilization at no less than $640{ }^{\circ} \mathrm{C}$ will impact reactivity or pyrophoricity when compared to stabilization at $950{ }^{\circ} \mathrm{C}$.

\subsubsection{Technical Position}

Elimination of pyrophoric materials in the HBL product will not be a concern because metal cannot credibly survive the aqueous chemical processes leading to plutonium oxalate. 
Substoichiometric oxides are not expected to be a concern for material stabilized in an oxidizing environment at $640{ }^{\circ} \mathrm{C}$ or greater. Any undissolved metallic fines from the H-Canyon dissolution process are removed by filtration prior to anion exchange, oxidized under the proposed stabilization conditions, or have very limited potential for reaction in air (e.g., platinum, nickel, etc.).

\subsubsection{Discussion of Available Data}

Sources of metal in the HBL process include Pu metal and the dissolvable carbon-steel cans in which the Pu metal will be repackaged prior to dissolution. The dissolution time and conditions are expected to be sufficient to completely dissolve all metal charged to the dissolver (Pierce, 2011; Rudisill and Pierce, 2012). In the unlikely event that any incompletely dissolved metal particles remain after dissolution and are transferred from the Canyon dissolver to HBL, some of the particles could persist in the process and be collected along with the oxalate precipitate during filtration. However, if any such fine particles were not oxidized by stabilization in air at $640{ }^{\circ} \mathrm{C}$ for $4 \mathrm{~h}$, they would be too unreactive or too dilute and too highly dispersed within the bulk oxide to be of concern for safe storage of the $\mathrm{PuO}_{2}$ product.

There is ample literature evidence demonstrating the effectiveness of thermal conversion of both $\mathrm{Pu}(\mathrm{IV})$ and $\mathrm{Pu}(\mathrm{III})$ oxalate to $\mathrm{PuO}_{2}$ at lower temperatures than being proposed for this equivalency even in inert atmosphere (Vigier et al., 2007; Myers, 1956). Conversion to $\mathrm{PuO}_{2}$ is complete by $400{ }^{\circ} \mathrm{C}$ in air and by $600{ }^{\circ} \mathrm{C}$ in inert atmosphere, although the studies do not focus on trace residual reactant or intermediates. Waterbury et al. (1961) found the $\mathrm{O} / \mathrm{Pu}$ atom ratios following calcination of $\mathrm{Pu}(\mathrm{IV})$ oxalate in air varied from 2.044 at $330{ }^{\circ} \mathrm{C}$ to 2.014 after $4 \mathrm{~h}$ at $1250^{\circ} \mathrm{C}$; thus, substoichiometric oxides are not anticipated in the HBL product.

\subsubsection{Data Gaps}

None.

\subsection{Elimination of Organic Materials}

\subsubsection{Issue Statement}

The stabilization process has an objective to destroy or drive off organics that may be present in $\mathrm{PuO}_{2}$ materials to minimize the potential for radiolytic or thermal degradation that may lead to gas generation (particularly hydrogen) during storage. The question is whether stabilization at $640{ }^{\circ} \mathrm{C}$ will result in a product that contains unacceptably high levels of residual organic species compared to materials stabilized at $950^{\circ} \mathrm{C}$.

\subsubsection{Technical Position}

Published studies indicate that conversion of plutonium oxalate to $\mathrm{PuO}_{2}$ proceeds to completion below $600{ }^{\circ} \mathrm{C}$. Calcination at no less than $640{ }^{\circ} \mathrm{C}$ for $4 \mathrm{~h}$ is expected to destroy oxalate and any other organics that may credibly be present in the product following oxalate precipitation. This is supported by previous analyses of neptunium dioxide $\left(\mathrm{NpO}_{2}\right)$ produced in HBL by a similar process which determined the $\mathrm{C}$ content to be well below $1000 \mu \mathrm{g} / \mathrm{g} \mathrm{NpO}$ (Duffey, 2008). HBL product specifications require the $\mathrm{C}$ content to be $\leq 1000 \mu \mathrm{g} / \mathrm{g}$ of Pu. Formal requirement that the product specification has been met would assure that the residual carbon content is consistent with essentially complete conversion and not of concern for gas generation in the 3013 container. The acceptable $\mathrm{C}$ content must be demonstrated either by $\mathrm{C}$ measurement for each batch of $\mathrm{PuO}_{2}$ or by process qualification. 


\subsubsection{Discussion of Available Data}

The primary source of organic compounds in the HBL process is the addition of oxalic acid to precipitate plutonium(IV) oxalate. Although the oxalate ion $\left(\mathrm{C}_{2} \mathrm{O}_{4}{ }^{2-}\right)$ contains no $\mathrm{H}$ atoms and, therefore, is not a concern for $\mathrm{H}_{2}$ generation, radiolytic or thermolytic decomposition of $\mathrm{C}_{2} \mathrm{O}_{4}{ }^{2-}$ to produce $\mathrm{CO}$ or $\mathrm{CO}_{2}$ is a plausible source for gas generation. In addition to oxalate, other potential sources of organic material in the HBL product are the nylon bags which contain the dissolvable carbon-steel cans of Pu metal, resin fines that pass through the anion column screen holding the resin in place, and Kynar from the precipitator paddle blades. Residual oxalate, resin, and Kynar were previously investigated by Crowder and Kyser (2009) as potential sources of $\mathrm{C}$ in $\mathrm{NpO}_{2}$ produced by HBL. They concluded that residues of these materials were not present to any significant degree in the samples of $\mathrm{HBL} \mathrm{NpO}_{2}$ product examined, and these materials would have been detectable by TGA-MS analysis of the oxide product if they were present.

The nylon bags used in the dissolution process in H-Canyon have previously been shown to dissolve in $\mathrm{HNO}_{3}-\mathrm{KF}$ solutions such as will be used in this process (Kessinger and Clark, 2004). Organic material remaining in solution after dissolution would be transferred to HBL and either trapped on the resin or washed through the column. If trapped on the resin, some material could be eluted with the Pu product and end up in the oxalate precipitate. It is also conceivable that resin fines from the anion exchange process or Kynar from the precipitator paddle blades could be abraded and be incorporated in the oxalate precipitate.

Nylon is a family of thermoplastic polymers, generally referred to as polyamides, consisting of $\mathrm{C}$, $\mathrm{H}, \mathrm{O}$, and $\mathrm{N}$ atoms. Reillex ${ }^{\mathrm{TM}} \mathrm{HPQ}$ is a strong-base macroporous anion exchange resin composed of a copolymer backbone of 1-methyl-4-vinylpyridine and a divinylbenzene mixture (Crooks et al., 2000). Kynar is a thermoplastic fluoropolymer (poly-1,1-difluoroethene) consisting of C, H, and $\mathrm{F}$ atoms. Boak et al. (2002) report from the literature that decomposition of hydrocarbons and Cl-containing organics in air is essentially complete by $600{ }^{\circ} \mathrm{C}$, the maximum rate of decomposition of rubbers occurs at less than $470{ }^{\circ} \mathrm{C}$ and is complete by $700{ }^{\circ} \mathrm{C}$, and that decomposition of F-containing organics such as Teflon ${ }^{\circledR}$ begins around $350{ }^{\circ} \mathrm{C}$ with no further mass loss obtained above $750{ }^{\circ} \mathrm{C}$. Therefore, all three sources of organic material identified above that may conceivably be incorporated in the plutonium oxalate precipitate are expected to be largely or completely decomposed by stabilization to no less than $640{ }^{\circ} \mathrm{C}$ in air for $4 \mathrm{~h}$. Furthermore, any significant amount of undecomposed organic material remaining in the stabilized product would result in a failure to meet the product specification for carbon.

Several research groups have studied the thermal decomposition of $\mathrm{Pu}$ oxalate under both oxidizing and inert atmospheres. Most researchers followed mass loss as a function of temperature using thermobalances, using that data to identify intermediate products as well as temperature of completion of the conversion to $\mathrm{PuO}_{2}$. Some studies have removed material from the thermobalance at intermediate stages of the decomposition to try to identify intermediate products using additional analytical techniques such as X-ray diffraction and infrared or UV-Vis spectroscopy. Early work is summarized in Cleveland (1979). Subsequent studies have added information on the decomposition steps by using techniques such as infrared spectroscopy to identify reaction intermediates (Nissen, 1980; Karelin et al., 1990; Vigier et al., 2007).

There is general agreement that decomposition proceeds to complete conversion to $\mathrm{PuO}_{2}$ regardless of whether the initial oxalate compound contains $\mathrm{Pu}(\mathrm{III})$ or $\mathrm{Pu}(\mathrm{IV})$ and regardless of whether the material is heated in an inert or an oxidizing atmosphere. In these laboratory-scale studies, the conversion to $\mathrm{PuO}_{2}$ is complete below $400{ }^{\circ} \mathrm{C}$ in air and below $600{ }^{\circ} \mathrm{C}$ in an inert atmosphere such as argon. 


\subsubsection{Data Gaps}

The oxalate decomposition literature regards a reaction as having reached completion when the rate of change is negligible relative to the rate of change early in the process. These studies generally have not focused on quantifying the residual trace $C$ as a function of calcination temperature. It may be necessary to adjust conditions to meet the product $\mathrm{C}$ specification of $\leq 1000 \mu \mathrm{g} / \mathrm{g} \mathrm{Pu}$.

As part of flow sheet evaluation for the proposed HBL process, it is a requirement that the $\mathrm{C}$ content of $\mathrm{PuO}_{2}$ produced according to this flow sheet (Christopher, 2011) is below $1000 \mu \mathrm{g} / \mathrm{g} \mathrm{Pu}$. Tests currently underway in SRNL to prepare a demonstration batch of $\mathrm{PuO}_{2}$ per the nominal HBL flow sheet and characterize the product, including measuring total C (Crowder and Duffey, 2011) will help to fill some of the existing data gaps.

\subsection{Reduction of Content of Water and Other Water-Producing Species}

\subsubsection{Issue Statement}

To be judged as effective, stabilization must reduce total moisture content to below $0.5 \mathrm{wt} \%$. This objective is intended primarily to mitigate against internal pressurization of a container due to radiolysis of moisture. For HBL oxide, the question is whether stabilization at $640{ }^{\circ} \mathrm{C}$ will remove water and other water-producing species so the residual water content is $<0.5 \mathrm{wt} \%$. In general, for oxide materials there is potential for physically adsorbed water, waters associated with hydrated compounds, and the surface hydroxide component of water associated with $\mathrm{PuO}_{2}$ and other metal oxides. For high-purity $\mathrm{PuO}_{2}$ from the HBL process, the primary concerns are physically adsorbed water and surface hydroxides.

\subsubsection{Technical Position}

Moisture measurement by an approved method, which includes heating to $1000{ }^{\circ} \mathrm{C}$ and measuring the volatilized moisture or the resulting weight loss after the sample cools (DOE, 2012), will verify that less than $0.5 \mathrm{wt} \%$ moisture remains in the stabilized HBL oxide product. Any sample failing this criterion will be stabilized again. Stabilization at no less than $640{ }^{\circ} \mathrm{C}$ for $4 \mathrm{~h}$ will drive off virtually all water and hydroxides (Veirs, 2002). It is expected that a small quantity of chemisorbed water (i.e., hydroxyl layer) well below $0.5 \mathrm{wt} \%$ will survive stabilization.

\subsubsection{Discussion of Available Data}

The specific $0.5 \mathrm{wt} \%$ limit is based on the limiting case assumption of complete conversion of the hydrogen content of water to $\mathrm{H}_{2}$ gas, and the ability of a 3013 container to withstand the resulting internal pressure with an adequate safety margin (DOE, 2012). Achievement of this objective is the primary purpose of the 3013 requirements of thermally stabilizing to $950{ }^{\circ} \mathrm{C}$ for two hours followed by analysis of the residual moisture. Previous stabilization and packaging campaigns produced extensive data on the total volatiles after stabilization of $\mathrm{PuO}_{2}$ to $950{ }^{\circ} \mathrm{C}$, all of which was assumed to be moisture for the purposes of certifying compliance with the $0.5 \mathrm{wt} \%$ moisture limit. A much smaller set of data is available showing the temperature dependence of the thermal desorption of moisture from oxide stabilized to $950{ }^{\circ} \mathrm{C}$. Generally the moisture found on the material is ascribed to a combination of a surface hydroxide layer and one or more monolayers of more loosely bound adsorbed water molecules. There is strong evidence that the loosely-bound monolayers of $\mathrm{H}_{2} \mathrm{O}$ on the oxide surface will be desorbed using the proposed stabilization process at $640{ }^{\circ} \mathrm{C}$ or greater (DOE, 2012; Berg et al., 2012; Veirs et al., 2012). The principal concern for this form of moisture would be prevention of adsorption or re-adsorption between stabilization and packaging. Because the product oxide from the proposed low 
temperature stabilization process is expected to have significantly higher SSA than oxide stabilized to $950{ }^{\circ} \mathrm{C}$, adsorption or re-adsorption has the clear potential to lead to a total moisture content exceeding $0.5 \mathrm{wt} \%$.

Thermal desorption profiles from $\mathrm{PuO}_{2}$ after stabilization at $950{ }^{\circ} \mathrm{C}$ also consistently show a small moisture component that is volatilized above the proposed stabilization temperature of $640{ }^{\circ} \mathrm{C}$ or greater. The data suggest, but do not prove, that this component may form over weeks to months from $\mathrm{H}_{2} \mathrm{O}$ already on the material in other forms or from $\mathrm{H}_{2} \mathrm{O}$ vapor available in the storage atmosphere (Veirs et al., 2012). It is possible that material with a higher specific surface area would have significantly greater capacity for moisture that would not be removed under the proposed stabilization conditions. In that case, the result would be high rates of failure to meet the $0.5 \mathrm{wt} \%$ moisture criterion, which would be identified by the required moisture measurements prior to packaging.

\subsubsection{Data Gaps}

Existing data show that some moisture incorporated into batches of pure $\mathrm{PuO}_{2}$ is not thermally volatilized at the proposed stabilization temperature (Berg et al., 2012; Veirs et al., 2012). No test data has been identified that quantifies the capacity for such moisture in the case of higher surface area $\mathrm{PuO}_{2}$. If the ultimate capacity for such tightly-bound moisture is high enough to result in potential failure to meet the $0.5 \mathrm{wt} \%$ criterion, information on kinetics of its formation would be important in avoiding high failure rates. The data gaps indicate unknown risk of failure to meet the $0.5 \mathrm{wt} \%$, a risk that could not be mitigated by restrictions on post-stabilization handling of the oxide. Moisture measurements and moisture uptake studies planned for $\mathrm{PuO}_{2}$ that will be produced in SRNL per the nominal HBL flow sheet (Crowder and Duffey, 2011) are expected to fill some of the data gaps. However, non-compliant material would still be identified by the prepackaging moisture measurement process.

\subsection{Minimization of Potential for Adsorption or Readsorption of Water}

\subsubsection{Issue Statement}

The potential for water adsorption depends on the availability of water, usually as water vapor in the post-stabilization handling atmosphere, and on the affinity of the material for moisture, whether through surface adsorption or chemical incorporation. Thermal stabilization to higher temperature than strictly required for oxalate decomposition serves to reduce the material surface area, thereby reducing the potential of the stabilized material to adsorb water upon cooling. For the HBL product, the question is whether stabilization at $640{ }^{\circ} \mathrm{C}$ for $4 \mathrm{~h}$ will be sufficient to reduce the oxide SSA and decrease potential for water adsorption so the product can be maintained at $<0.5 \mathrm{wt} \%$ water if allowed to equilibrate with the handling atmosphere, or whether measures will be necessary to prevent the equilibrium condition from being achieved.

\subsubsection{Technical Position}

Moisture measurement will verify that less than $0.5 \mathrm{wt} \%$ moisture remains in the stabilized HBL oxide product immediately after stabilization and at the time of packaging. Any sample failing this criterion will be stabilized again. Process controls (which may include additional moisture measurements) and an integrated surveillance program will confirm the moisture content remains below $0.5 \mathrm{wt} \%$ including measurement uncertainty for packaged materials. This approach does not require specific limits on handling time and handling conditions except as necessary to assure that the measured moisture on the sample remains representative or bounding of the moisture on the parent batch at the time of packaging. However, due to the increased potential for hydrogen plus oxygen generation for high-purity oxide exposed to high $\mathrm{RH}$, the $\mathrm{RH}$ at the stabilized oxide 
surface (i.e., lowest material temperature) should be limited to 60\% (Veirs et al., 2012). Furthermore, it is necessary to minimize exposure of the batch to a humid atmosphere, as the SSAs will be large enough that the material will fail the $0.5 \mathrm{wt} \%$ moisture criterion if equilibrated with such an atmosphere.

\subsubsection{Discussion of Available Data}

Water adsorption by high-purity $\mathrm{PuO}_{2}$ produced from oxalate precipitation is primarily a function of RH, SSA, and temperature (Veirs, 2002). The potential for water adsorption is an important consideration for the proposed HBL product due to the expected high product SSAs (i.e., 5$15 \mathrm{~m}^{2} / \mathrm{g}$ ) and high processing RH (i.e., 40-70\%) in HBL. These conditions increase the potential for the HBL product to exceed the $0.5 \mathrm{wt} \%$ moisture limit and will increase the potential for $\mathrm{H}_{2}$ and $\mathrm{O}_{2}$ gas generation (Veirs et al., 2012).

$\mathrm{PuO}_{2}$ produced at LANL for MOX LTA during the time frame of 2001-2008 using a flow sheet similar to what is planned for HBL had measured SSAs ranging from $5-15 \mathrm{~m}^{2} / \mathrm{g}$ with an average $( \pm 1 \sigma)$ of $9.8 \pm 1.8 \mathrm{~m}^{2} / \mathrm{g}$ (Alwin, 2007; Bluhm, 2005). A broader survey of the literature on the dependence of SSA on calcination temperature (Daniel, 2012) shows that SSAs in this range for $\mathrm{HBL}$ product would be consistent with that observed in other laboratories. Laboratory-scale $\mathrm{PuO}_{2}$ samples produced in support of the HBL MOX feed mission (Crowder and Duffey, 2011; Crowder et al., 2012) also have SSAs in this range.

Based on Brunauer-Emmett-Teller (BET) adsorption isotherm theory as well as experimental observations of water adsorption on $\mathrm{PuO}_{2}$ (Haschke and Ricketts, 1997), the number of monolayer equivalents (ML) of water adsorbed by $\mathrm{PuO}_{2}$ at equilibrium increases from about 1.5 ML at 30\% RH to about $2 \mathrm{ML}$ at 50\% RH and to more than $3 \mathrm{ML}$ at 70\% RH (Veirs et al., 2012). One ML is equal to about $0.22 \mathrm{mg} \mathrm{H}_{2} \mathrm{O} / \mathrm{m}^{2}$ of oxide surface; therefore, $\mathrm{PuO}_{2}$ with a SSA of 10 $\mathrm{m}^{2} / \mathrm{g}$ in equilibrium with a $\mathrm{RH}$ of $50 \%$ would adsorb an amount of water equal to about $0.44 \mathrm{wt} \%$, and if equilibrated at higher RH would exceed $0.5 \mathrm{wt} \%$.

Based on a review of the available data for $\mathrm{O}_{2}$ generation by high-purity $\mathrm{PuO}_{2}$, Veirs et al. (2012) also conclude that a minimum of $2 \mathrm{ML}$ of adsorbed water is required for production of $\mathrm{H}_{2}$ and $\mathrm{O}_{2}$. Furthermore, under HBL processing conditions it is possible to produce $\mathrm{PuO}_{2}$ that will adsorb $2 \mathrm{ML}$ of water with $<0.5 \mathrm{wt} \%$ total water content.

Because there is a possibility that HBL product may produce $\mathrm{H}_{2}$ and $\mathrm{O}_{2}$, determination of the maximum attainable pressure is required to demonstrate packaging integrity. Veirs et al. (2012) conclude that the maximum pressure that could be generated in a 3013 container by $5000 \mathrm{~g}$ of high-purity $\mathrm{PuO}_{2}$ with SSA in the range expected for HBL product equilibrated with $60 \% \mathrm{RH}$ and containing $<0.5 \mathrm{wt} \%$ water is $277 \mathrm{kPa}$ (Table 1). This calculated pressure assumes (1) that both a strongly bound layer (SBL) of chemisorbed water equivalent to $0.5 \mathrm{ML}$ and up to two ML of molecular (physisorbed) water are not available to generate pressure by radiolysis, and (2) all of the water beyond these first $2.5 \mathrm{ML}$ is completely converted to a stoichiometric mixture of $\mathrm{H}_{2}$ and $\mathrm{O}_{2}$ gas. Figure 3 illustrates the sensitivity of the maximum calculated pressure to changes in equilibrium RH (i.e., the pressure increases about $60 \mathrm{kPa}$ for every $1 \% \mathrm{RH}$ increase) for $5000 \mathrm{~g}$ of the same high-purity material using the same conditions evaluated in Table 1 . The conditions selected for calculating the pressure data presented in Table 1, are considered most representative of the HBL product (Veirs et al., 2012). The expression for $\mathrm{c}$ as used in the construction of Table 1 and Figure 3 is $\mathrm{c}=\mathrm{e}^{\Delta \mathrm{H} / \mathrm{RT}}$, where $\Delta \mathrm{H}$ is the excess heat of adsorption compared to the heat of condensation of the liquid. 
Table 1. Calculated maximum pressures in $\mathrm{kPa}$ as a function of the mass of oxide and the $\mathrm{RH}$ the material experiences using $\mathrm{T}=35^{\circ} \mathrm{C}, \mathrm{c}=7$, and $\mathrm{SBL}=0.5$.

\begin{tabular}{|c|c|c|c|c|c|}
\hline $\begin{array}{c}\text { Mass } \\
(\mathrm{g})\end{array}$ & $70 \%$ & $65 \%$ & $60 \%$ & $55 \%$ & $50 \%$ \\
\hline 5000 & 876 & 579 & 277 & 0 & 0 \\
\hline 4500 & 770 & 509 & 243 & 0 & 0 \\
\hline 4000 & 669 & 442 & 211 & 0 & 0 \\
\hline 3500 & 572 & 378 & 181 & 0 & 0 \\
\hline 3000 & 480 & 317 & 152 & 0 & 0 \\
\hline 2500 & 391 & 258 & 124 & 0 & 0 \\
\hline 2000 & 306 & 202 & 97 & 0 & 0 \\
\hline 1500 & 225 & 149 & 71 & 0 & 0 \\
\hline 1000 & 147 & 97 & 46 & 0 & 0 \\
\hline
\end{tabular}

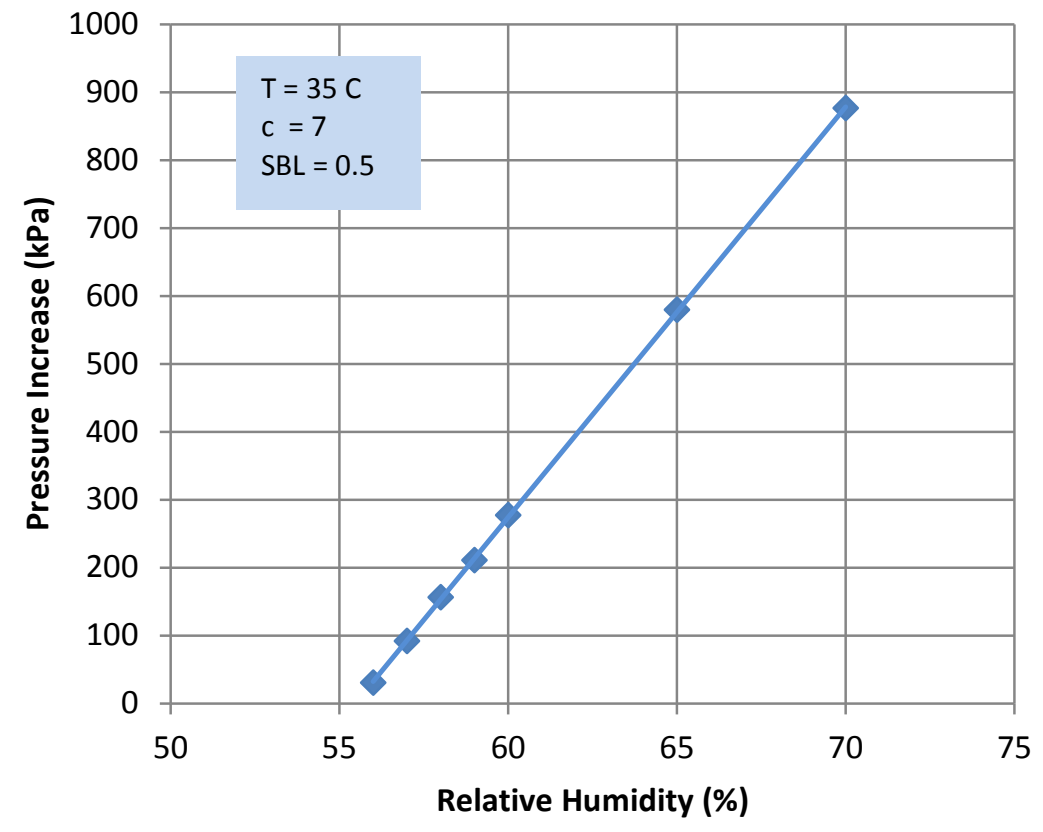

Figure 3. Calculated maximum pressure as a function of equilibrium $\mathrm{RH}$ for $5000 \mathrm{~g}$ of $\mathrm{PuO}_{2}$.

Rawls et al. (2010) carried out a series of tests to determine the threshold for deflagration-todetonation transition (DDT), structural loading, and structural response of the 3013 container in the event of an accidental explosion of evolved gas within the storage container (Liang and Shepherd, 2007a-c). They concluded that DDT of a stoichiometric mixture of $\mathrm{H}_{2}$ and $\mathrm{O}_{2}$, as well as mixtures diluted with nitrogen and helium, within the 3013 container at initial pressures up to 3.5 bar $(350 \mathrm{kPa})$ does not threaten the structural integrity of the outer container. Furthermore, Rawls (2012) evaluated the possibility of an HBL 3013 container explosion with an initial pressure of $380 \mathrm{kPa}$ (i.e., approximately $100 \mathrm{kPa}$ nitrogen and approximately $280 \mathrm{kPa}$ stoichiometric hydrogen-oxygen) and concluded there is sufficient structural capacity in the 3013 container to prevent failure. Therefore, generation of both $\mathrm{H}_{2}$ and $\mathrm{O}_{2}$ by $\mathrm{HBL}$ product exposed to 
$\leq 60 \% \mathrm{RH}$ and containing up to $0.5 \mathrm{wt} \%$ water is not expected to exceed the conditions evaluated by Rawls (2012) and will not pose a threat to the structural integrity of the 3013 container.

\subsubsection{Data Gaps}

The rate of water adsorption of large batches (i.e., 1-3 kg per container) of freshly stabilized oxide within HBL is not known. The rate is likely conservatively bounded by laboratory smallscale studies, since deeper oxide beds will provide more resistance to water diffusion and mass transfer than the shallow samples used in laboratory testing. Nevertheless, laboratory sample equilibration times are relatively low (i.e., minutes to hours) and would lead to the expectation that the surface would be fully equilibrated by adsorbing moisture prior to packaging (Berg et al., 2012; Haschke and Ricketts, 1997). In any case, non-compliant material would still be identified by the pre-packaging moisture measurement process.

\subsection{Stabilization of Potential Gas-Producing Constituents}

\subsubsection{Issue Statement}

Stabilization must meet the objective of effectively removing other non-moisture, gas-producing impurities such as nitrates $\left(\mathrm{NO}_{3}{ }^{-}\right)$, sulfates $\left(\mathrm{SO}_{4}{ }^{2-}\right)$, and carbonates $\left(\mathrm{CO}_{3}{ }^{2-}\right)$ in $\mathrm{PuO}_{2}$. The question is whether stabilization at $640{ }^{\circ} \mathrm{C}$ for $4 \mathrm{~h}$ will be sufficient to eliminate or reduce to acceptable levels such impurities in the HBL product.

\subsubsection{Technical Position}

With no valence adjustment step in the HBL process, there is no credible source of $\mathrm{SO}_{4}{ }^{2-}$ after dissolution (Kyser and King, 2012). Nitrate is plentiful because the process occurs in $\mathrm{HNO}_{3}$ solution, but the bulk of the $\mathrm{HNO}_{3}$ is removed during the anion exchange and oxalate precipitation steps, and residual $\mathrm{NO}_{3}{ }^{-}$is expected to be decomposed by stabilization at $640{ }^{\circ} \mathrm{C}$ or greater for $4 \mathrm{~h}$ (Boak et al., 2002; Waterbury et al., 1961). Although some residual $\mathrm{CO}_{3}{ }^{2-}$ could result from incomplete decomposition of oxalate, the relatively small amounts of $\mathrm{C}$, as well as $\mathrm{N}^{6}$ and S, allowed per specification in the $\mathrm{HBL} \mathrm{PuO}_{2}$ product $(1000 \mu \mathrm{g} / \mathrm{g}, 400 \mu \mathrm{g} / \mathrm{g}$, and $250 \mu \mathrm{g} / \mathrm{g}$ of $\mathrm{Pu}$, respectively) do not pose a significant gas generation concern. Significantly higher levels of each impurity have been present in material stored for five to ten years in 3013 containers (Kessinger et al., 2010), and in material subjected to shelf-life tests for up to ten years (Berg et al., 2012), and in no case have they led to levels of gas generation that are of concern for overpressurizing a 3013 container (Almond et al., 2010).

\subsubsection{Discussion of Available Data}

Both shelf-life studies and destructive examinations of production containers have shown that some thermally stabilized impure oxides can release minor quantities of $\mathrm{CO}_{2}$ and $\mathrm{CO}$ into the container headspace during storage (Duffey et al. 2010; Almond et al., 2010). The quantities are far below levels of concern for pressurization. Destructive evaluations of containers with up to $1.4 \mathrm{wt} \%$ total carbon have shown partial pressures of $\mathrm{CO}_{2}$ no higher than $5 \mathrm{kPa}$ after more than five years of storage.

Shelf-life studies of gas generation at LANL have included several tests on material (MISSTD-1) from a parent lot of pure oxide that was prepared by calcining $\mathrm{Pu}(\mathrm{III})$ oxalate at $600{ }^{\circ} \mathrm{C}$ for six hours (Berg et al., 2012). Total carbon content of the parent was measured as $0.29 \mathrm{wt} \%$. The

\footnotetext{
${ }^{6} \mathrm{H}$-Area is not required to verify the nitrogen levels in the product. MOX Services will confirm the nitrogen limits are met with statistical sampling and analysis prior to dissolving.
} 
partial pressure of $\mathrm{CO}_{2}$ in 1:500 scale containers with 10 grams of material heated to $55{ }^{\circ} \mathrm{C}$ had risen to $1.1 \mathrm{kPa}$ three months after the start of the test and was at the same value one year later. A kilogram-scale test on the same material showed only $0.02 \mathrm{kPa} \mathrm{CO}$ when the headspace gas was sampled after approximately 10 years.

Other LANL shelf-life experiments on pure oxides calcined to $950{ }^{\circ} \mathrm{C}$ observed somewhat higher levels of $\mathrm{CO}_{2}$, though still far below a level of concern for container pressurization. For example, TS707001 produced a maximum of $30 \mathrm{kPa}$ of $\mathrm{CO}_{2}$ (Duffey et al., 2010). Chemical analysis indicated less than $0.01 \mathrm{wt} \%$ carbon. The SSA of this material was measured at $2.3 \mathrm{~m}^{2} / \mathrm{g}$, much lower than that of MISSTD-1. Because of the low surface area and high water loading, $\mathrm{H}_{2} \mathrm{O}$ may effectively displace adsorbed carbon species from the surface and lead to a higher proportion in the gas phase. But even in these cases, volatile carbon-containing species are far below pressures that would raise concerns about container integrity.

In summary, all container surveillance and shelf-life studies indicate that carbon-containing species $\left(\mathrm{CO}_{2}\right.$, CO, etc.) are not significant contributors to headspace pressure even after years of storage. The carbon content of some of the materials in these studies has significantly exceeded the allowed level of $1000 \mu \mathrm{g} / \mathrm{g}$ Pu for the HBL product. Where carbon is present, operating experience indicates that it remains almost entirely in non-volatile forms.

\subsubsection{Data Gaps}

None.

\subsection{Conclusions and Recommendations}

The HBL process and associated controls required for supporting the stabilization of $\mathrm{PuO}_{2}$ at no less than $640{ }^{\circ} \mathrm{C}$ for $4 \mathrm{~h}$ have been evaluated and determined to generate a product equivalent, relative to meeting the DOE-STD-3013 criteria, to plutonium-bearing oxides currently packaged under the 3013 standard. The primary limitation identified by this report is the high-purity oxide produced in HBL will have a greater tendency to adsorb moisture than $\mathrm{PuO}_{2}$ stabilized at $950{ }^{\circ} \mathrm{C}$. By maintaining the $\mathrm{RH}$ at the product surface to $60 \%$ or less (including measurement uncertainty) and total moisture content to less than $0.5 \mathrm{wt} \%$ (including measurement uncertainty), the composition and pressure of gas generated by this product is bounded by the maximum acceptable pressure of a stoichiometric mixture of hydrogen and oxygen in the 3013 container (Rawls, 2012). This assessment is based on evaluation of available scientific literature for similar materials to define a conservative estimate of product performance. The margin associated with this evaluation relies on HBL implementing the following controls:

- Plutonium(IV) oxalate product is stabilized in an oxidizing atmosphere at no less than $640{ }^{\circ} \mathrm{C}$ for a total of $4 \mathrm{~h}$ or longer.

- The total product impurities shall be less than 23,600 $\mu \mathrm{g} / \mathrm{g} \mathrm{Pu}(2.1 \mathrm{wt} \%)$. Chloride plus fluoride content is limited to $250 \mu \mathrm{g} / \mathrm{g} \mathrm{Pu}$ and carbon content is limited to $5000 \mu \mathrm{g} / \mathrm{g} \mathrm{Pu}$. Variation in metallic impurities identified by MFFF limits are not a direct concern for this evaluation.

- $\mathrm{RH}$ at the product surface, taking into account any difference between ambient temperature and product temperature, needs to remain below $60 \% \mathrm{RH}$.

- Moisture samples will be collected near the container wall and represent the full volume of the product can. Any increase in mass by the product following sampling shall be conservatively addressed as part of the moisture analysis.

- Moisture analysis will use TGA or TGA-MS methods approved by the 3013 Standard and assure samples are heated to $1000{ }^{\circ} \mathrm{C}$ as part of the analysis. Total moisture content 
shall be less than $0.5 \mathrm{wt} \%$ including analytical uncertainty. ${ }^{7}$ Representative samples of the HBL product will be placed in the MIS program to validate material performance at the 0.5 wt \% moisture limit with samples representing both the high and low SSA values that are expected by the HBL process.

- Product wattage is limited only by restrictions on content imposed by the 3013 Standard "to ensure the heat generation rate of the contained materials will not exceed 19 watts at any time during the 50-year storage life” (DOE, 2012).

After reviewing the proposed $\mathrm{HBL}$ flow sheet for producing high-purity $\mathrm{PuO}_{2}$ for feed to the MFFF and available supporting data, the authors conclude that the proposed HBL process conditions are capable of producing $\mathrm{PuO}_{2}$ that poses no safety concern for packaging or storage in the 3013 required configuration, provided the stabilized product is handled in a way to minimize adsorption of water. The technical team also concludes that moisture adsorption by $\mathrm{PuO}_{2}$ stabilized to at least $640{ }^{\circ} \mathrm{C}$ for $4 \mathrm{~h}$ and handled in ambient air with a $\mathrm{RH}$ as high as $70 \%$ poses the greatest challenge to meeting the DOE-STD-3013 packaging requirements. As the RH increases above $60 \%$, the equilibrium moisture content increases to levels that increase the risk of exceeding the $0.5 \mathrm{wt} \%$ moisture content limit in a practical handling time.

The anticipated gas generation pressures and compositions for this product packaged with less than $0.5 \mathrm{wt} \%$ moisture will be within the limits of observations for materials previously evaluated by the MIS Shelf Life program. In all cases, the acceptable pressure of a mixture of hydrogen and oxygen in the 3013 container (Rawls, 2012) is greater than the maximum pressure calculated for the proposed HBL product. Incorporation of samples of actual HBL product into the MIS Shelf Life Program will ultimately validate the anticipated gas generation behavior of these materials.

\footnotetext{
${ }^{7}$ Previously, DOE sites have imposed measurement limits of 0.4 wt \% mass loss for TGA and 0.32 wt \% moisture by TGA-MS to ensure compliance with the $0.5 \mathrm{wt} \%$ moisture limit (see, e.g., McNew, 2003).
} 


\subsection{References}

Almond et al., 2010

Alwin, 2007

Berg et al., 2012

Bluhm, 2005

Boak et al., 2002

Boak et al., 2003

Christopher, 2011

Cleveland, 1979

Crooks et al., 2000

Crowder et al., 2012
Almond, Philip M.; Bridges, Nick J.; Kessinger, Glen F.; Duffey, Jonathan M.; Livingston, Ronald R.; Traver, Lance E.; Arnold, Matthew J. Gas Analyses from Headspace of Plutonium-bearing Materials Containers. J. Nucl. Mater. Manag. 2010, 38, 54-63.

Alwin, Jennifer L.; Coriz, Fawn; Danis, Jan A.; Bluhm, Brian K.; Wayne, David W.; Gray, Devin W.; Ramsey, Kevin B.; Costa, David A.; Bluhm, Elizabeth A.; Nixon, Archie E.; Garcia, Daniel J.; Roybal, Judy D.; Saba, Mark T.; Valdez, Jose A.; Martinez, David; Martinez, Joe R.; Martinez, Cathy M.; Martinez, Yvonne A.; Martinez, Carl M. Plutonium oxide polishing for MOX fuel fabrication. J. Alloys Compd. 2007, 444-445, 565-568.

Berg, John M.; Narlesky, Joshua E.; Veirs, Douglas K. A summary of volatile impurity measurements and gas generation studies on MISSTD-1, a high-purity plutonium oxide produced by lowtemperature calcination of plutonium oxalate; Technical Report No. LA-UR-12-21473; Los Alamos National Laboratory: Los Alamos, NM, May 2012.

Bluhm, Elizabeth A.; Abney, Kent D.; Balkey, Simon; Brock, Jason C.; Coriz, Fawn; Dyke, James T.; Garcia, Daniel J.; Griego, Brenda J.; Martinez, Benjie T.; Martinez, David; Martinez, Joe Ray; Martinez, Yvonne A.; Morgan, Lonny; Roybal, Judy D.; Valdez, Jose A. Plutonium Oxide Polishing for MOX Fuel Production Sep. Sci. Technol. 2005, 40, 281-296.

Boak, J. M.; Eller, P. G.; Erickson, R. M.; Murray, A.; Roberson, G. D. Technical Basis for Equivalency to DOE Standard 3013 Requirements of Lower Temperature Stabilization for Electrorefining-Derived Plutonium Oxides, Revision 1; Technical Report No. LA-UR-02-6054; Los Alamos National Laboratory: Los Alamos, NM, October 2002.

Boak, J.; Conrad, E. A.; Delegard, C. H.; Murray, A. M.; Roberson, G. D.; Venetz, T. J. Recommendations on Stabilization of Plutonium Material Shipped to Hanford from Rocky Flats; Technical Report No. LA-UR-03-3789; Los Alamos National Laboratory: Los Alamos, NM, June 2003.

Christopher, J. W. Flow Sheet Verification for HB-Line Plutonium Oxide Production PPT/FLT/Calcination Operations and 3013 Equivalency; Technical Task Request No. NMMD-HTS-2011-3178; Savannah River Nuclear Solutions: Aiken, SC, November 2011.

Cleveland, J. M. The Chemistry of Plutonium, American Nuclear Society, 1979, pp. 396-412.

Crooks, William J., III; Kyser, Edward A., III; Walter, Steven R. Qualification of Reillex HPQ Anion Exchange Resin for Use in SRS Process; Technical Report No. WSRC-TR-99-00317; Westinghouse Savannah River Company: Savannah River Site, Aiken, SC, March 2000.

Crowder, M. L.; Pierce, R. A.; Scogin, J. H.; Daniel, W. E.; King, W. D. Small-Scale Testing of Plutonium(IV) Oxalate Precipitation and Calcination to Plutonium Oxide to Support the MOX Feed Mission; 
Crowder and Duffey, 2011

Crowder and Kyser, 2009

Daniel, 2012

DOE, 2012

Duffey, 2008

Duffey et al., 2010

Duffey and

Livingston, 2002

Garrison and Clifton, 2012

Gupta et al., 2000

Hackney, 2011

Haschke and Ricketts, 1997

HBL, 2007
Technical Report No. SRNL-STI-2012-00338, Rev. 0; Savannah River Nuclear Solutions: Savannah River National Laboratory, Aiken, SC, June 2012.

Crowder, M. L.; Duffey, J. M. Task Technical and Quality Assurance Plan for Precipitation and Calcination of Plutonium(IV) Oxalate to Form Plutonium Oxide and Subsequent Gas Generation Studies to Support the MOX Feed Mission; Report No. SRNL-RP-2011-01657, Rev. 0; Savannah River Nuclear Solutions: Savannah River National Laboratory, Aiken, SC, December 2011.

Crowder, Mark L.; Kyser, Edward A., III. Investigations of Potential Carbon Sources in Neptunium Oxide Produced by HB-Line; Technical Report No. SRNL-TR-2009-00125; Savannah River Nuclear Solutions: Savannah River National Laboratory, Aiken, SC June 2009.

Daniel, W. E. Literature Review of $\mathrm{PuO}_{2}$ Calcination Time and Temperature Data for Specific Surface Area; Technical Report No. SRNL-TR-2011-00334, Rev. 0; Savannah River Nuclear Solutions: Savannah River National Laboratory, Aiken, SC, March 2012.

DOE Standard: Stabilization, Packaging, and Storage of PlutoniumBearing Materials; DOE-STD-3013-2012; U. S. Department of Energy, Washington, DC, March 2012.

Duffey, Jonathan M. Carbon/Sulfur Analysis of HB-Line Np Oxide Part 2 Product; Report No. SRNL-L3100-2008-00077, Rev. 0; Savannah River Nuclear Solutions: Savannah River National Laboratory, Aiken, SC, October 2008.

Duffey, Jonathan M.; Veirs, D. Kirk; Berg, John M.; Livingston, Ronald R. Pressure Development in Sealed Containers with Plutonium-bearing Materials. J. Nucl. Mater. Manag. 2010, 38(3), 32-42.

Duffey, Jonathan M.; Livingston, Ronald R. Gas Generation Testing of Plutonium Dioxide. Fifth Topical Meeting on DOE Spent Nuclear Fuel and Fissile Materials Management [CD-ROM]; American Nuclear Society: Charleston, SC, 2002.

Garrison, S. L.; Clifton, W. H., Jr. H-Canyon Flowsheet during HBLine Plutonium Oxide Production; Report No. SRNS-F3100-201200024; Savannah River Nuclear Solutions: Savannah River Site, Aiken, SC, March 2012.

Gupta, S. K.; McClard, J. W.; Poss, D. H., II; Rangus, A. P.; Seward, B. R. Savannah River Site Stabilization and Packaging Requirements for Plutonium Bearing Materials for Storage; Report No. G-ESR-G00035, Rev. 1; Westinghouse Savannah River Company: Savannah River Site, Aiken, SC, July 2000.

Hackney, Elizabeth R. Nuclear Materials Storage Project ISSC Program - Implementation of the Interim Safe Storage Criteria Program; Document No. N-ESR-K-00004, Rev. 18; Savannah River Nuclear Solutions: Savannah River Site, Aiken, SC, December 2011.

Haschke, John M.; Ricketts, Thomas E. Adsorption of water on plutonium dioxide. J. Alloys Compd. 1997, 252, 148-156.

Neptunium 237 P\&I Diagram Neptunium Column \#1 Process \& Instruments Savannah River Plant Bldg. 221H (U); Drawing No. W717334, Rev. 59; Westinghouse Savannah River Company: Savannah River Site, Aiken, SC, January 2007. 
Jurgensen et al., 2005

Karelin, 1990

Kessinger et al., 2010

Kessinger and Clark, 2004

Kyser and King, 2012

Liang and Shepherd, 2007a

Liang and Shepherd, 2007b

Liang and Shepherd, 2007c

Livingston and Duffey, 2001

McAlhany, 2012

McNew, 2003

Myers, 1956
Jurgensen, Arthur R.; Missimer, David M.; Rutherford, Ronny L. Surface Area (BET) and TGA-MS Analysis of Calcined Neptunium Oxide (U), Technical Report No. WSRC-TR-2003-00378, Rev. 0; Westinghouse Savannah River Company: Savannah River Site, Aiken, SC, December 2005.

Karelin, A. I.; Krot, N. N.; Kozlova, R. D.; Lobas, O. P.; Matukha, V. A. Thermal decomposition of neptunium(IV) and plutonium(III,IV) oxalates. J. Radioanal. Nucl. Chem., 1990, 143, 241-252.

Kessinger, Glen F.; Almond, Philip M.; Bridges, Nick J.; Bronikowski, Mike G.; Crowder, Mark L.; Duffey, Jonathan M.; Missimer, Dave M.; Scogin, John H.; Summer, Michael E.; Livingston, Ronald R.; McElwee, Morgan M.; Jurgensen, Art R. Material Properties of Plutonium-bearing Oxides Stored in Stainless Steel Containers. J. Nucl. Mater. Manag. 2010, 38(3), 82-95.

Kessinger, G. F.; Clark, J. D. Nylon Dissolution in Nitric Acid Solutions; Technical Report No. WSRC-TR-2004-00329, Rev. 0; Westinghouse Savannah River Company: Savannah River Site, Aiken, SC, June 2004.

Kyser, E. A.; King, W. D. HB-Line Anion Exchange Purification of AFS-2 Plutonium for MOX; Technical Report No. SRNL-STI-201200233, Rev. 0; Savannah River Nuclear Solutions: Savannah River National Laboratory, Aiken, SC, April 2012.

Liang, Z.; Shepherd, J. E. Explosion Testing of Nested Can Containment System - Part I: Planar Gap; Laboratory Report No. FM2007.001; Graduate Aeronautical Laboratories: California Institute of Technology, Pasadena, CA, May 2007.

Liang, Z.; Shepherd, J. E. Explosion Testing of Nested Can Containment System - Part II: Thick-walled Tube; Laboratory Report No. FM2007.001; Graduate Aeronautical Laboratories: California Institute of Technology, Pasadena, CA, May 2007.

Liang, Z.; Shepherd, J. E. Explosion Testing of Nested Can Containment System - Part III: 3013 Outer Can; Laboratory Report No. FM2007.001; Graduate Aeronautical Laboratories: California Institute of Technology, Pasadena, CA, May 2007.

Livingston, Ronald R.; Duffey, Jonathan M. Effects of Plutonium Dioxide Moisture Content and Calcination Temperature on the Headspace Gas Composition of Sealed Containers; Technical Report No. WSRC-TR-2001-00420, Rev. 0; Westinghouse Savannah River Company: Savannah River Site, Aiken. SC, September 2001.

McAlhany, Sachiko. Mixed Oxide Fuel Fabrication Facility (MFFF)

- H-Area/K-Area Plutonium Oxide Powder Interface Control Document; ICD-11-032-01; Report No. G-ESR-H-00189, Rev. 0; National Nuclear Security Administration: Savannah River Site, Aiken, SC, June 2012.

McNew, R. Control and Measurement of Moisture in Plutonium Oxides Stabilized in FB-Line; Document No. NMM-EFL-03-063, Rev. 1; Westinghouse Savannah River Company: Savannah River Site, Aiken, SC, June 2003.

Myers, M. N. Thermal Decomposition of Plutonium(IV) Oxalate and Hydrofluorination of Plutonium(IV) Oxalate and Oxide; Technical Report No. HW-45128; General Electric Company: Hanford Atomic 
Nissen, 1980

Pierce, 2011

Rawls et al., 2010

Rawls, 2012

Rudisill and Pierce, 2012

Smith, 2012

Veirs, 2002

Veirs et al., 2012

Vigier et al., 2007

Waterbury et al., 1961
Products Operation, Richland, WA, August 1956.

Nissen, D. A. The thermal decomposition of plutonium(IV) oxalate hexahydrate, J. Therm. Anal. 1980, 18, 99-109.

Pierce, R. H. Dissolution Rate Measurements of Plutonium Metal in 8-10 M Nitric Acid; Inter-Office Memorandum No. SRNL-L31002011-00209; Savannah River Nuclear Solutions: Savannah River National Laboratory, Aiken, SC, November 2011.

Rawls, George B., Jr.; Prenger, F. Coyne; Shepherd, Joe E.; Liang, Zhe. Pressure Integrity of 3013 Container Under Postulated Accident Conditions. J. Nucl. Mater. Manag. 2010, 38(3), 43-53.

Rawls, G. B. HB Line 3013 Container Explosion Evaluation with Increased Initial Pressure; Letter Report No. SRNL-L4400-201200020; Savannah River National Laboratory: Savannah River Site, Aiken, SC, June 2012.

Rudisill, T. S.; Pierce, R. A. Dissolution of Plutonium Metal in 8-10 M Nitric Acid; Technical Report No. SRNL-STI-2012-00043, Rev. 0; Savannah River Nuclear Solutions: Savannah River National Laboratory, Aiken, SC, February 2012.

Smith, R. H. HB-Line Pu-239 Production Flow Sheet Strategy (U); Report No. SRNS-E-1100-2011-00025; Savannah River Nuclear Solutions: Savannah River Site, Aiken, SC, January 2012.

Veirs, D. Kirk; Mason, Richard E.; Erickson, Randall M. Water sorption mechanisms for MIS materials; Technical Report No. LAUR-02-5103; Los Alamos National Laboratory: Los Alamos, NM, September 2002.

Veirs, Douglas K.; Berg, John M.; Crowder, Mark L. The effect of plutonium dioxide water surface coverage on the generation of hydrogen and oxygen; Technical Report No. LA-UR-12-22377; Los Alamos National Laboratory: Los Alamos, NM, June 2012.

Vigier, N.; Grandjean, S.; Arab-Chapelet, B.; Abraham, F. Reaction mechanisms of the thermal conversion of $\mathrm{Pu}(\mathrm{IV})$ oxalate into plutonium oxide. J. Alloys Compd. 2007, 444-445, 594-597.

Waterbury, Glenn R.; Douglass, Robert M.; Metz, Charles F. Thermogravimetric Behavior of Plutonium Metal, Nitrate, Sulfate, and Oxalate. Anal. Chem. 1961, 33 (8), 1018-1023. 
SRNL-STI-2012-00256

Revision 0

Appendix A. Chemical Impurity Limits for HB-Line Feed to MFFF 
Table A-1. Chemical Impurity Limits for HB-Line Feed to MFFF

\begin{tabular}{|c|c|c|}
\hline Chemical Component & $\begin{array}{c}\text { Maximum Content }^{\mathrm{a}} \\
(\mu \mathrm{g} / \mathrm{g} \text { Pu })\end{array}$ & $\begin{array}{c}\text { Maximum Exceptional } \\
\text { Content }^{\mathbf{b}} \\
(\mu \mathrm{g} / \mathrm{g} \mathrm{Pu})\end{array}$ \\
\hline Ag (silver) & 250 & 10,000 \\
\hline Al (aluminum) & 500 & 10,000 \\
\hline B (boron) & 100 & 1000 \\
\hline Be (beryllium) & 100 & 2000 \\
\hline Bi (bismuth) & 100 & 1000 \\
\hline C (carbon) & 1000 & 5000 \\
\hline Ca (calcium) & 500 & 10,000 \\
\hline Cd (cadmium) & 10 & 1000 \\
\hline Cl (chlorine) & $(+F<250)$ & 500 \\
\hline Co (cobalt) & 100 & 10,000 \\
\hline Cr (chromium) & 1000 & 1500 \\
\hline Cu (copper) & 100 & 500 \\
\hline Dy (dysprosium) & 1 & 1000 \\
\hline Eu (europium) & 1 & 1000 \\
\hline F (fluorine) & $(+\mathrm{Cl}<250)$ & 350 \\
\hline Fe (iron) & 2000 & 3000 \\
\hline Ga (gallium) & 12,000 & 12,500 \\
\hline Gd (gadolinium) & 3 & 250 \\
\hline In (indium) & 20 & 1000 \\
\hline K (potassium) & 300 & 10,000 \\
\hline Li (lithium) & 400 & 10,000 \\
\hline Mg (magnesium) & 500 & 10,000 \\
\hline Mn (manganese) & 100 & 1000 \\
\hline Mo (molybdenum) & 100 & 1000 \\
\hline $\mathrm{N}$ (nitrogen) ${ }^{\mathrm{c}}$ & 400 & 400 \\
\hline $\mathrm{Na}$ (sodium) & 1000 & 10,000 \\
\hline Nb (niobium) & 100 & 3500 \\
\hline $\mathrm{Ni}$ (nickel) & 5000 & 12,000 \\
\hline P (phosphorus) & 200 & 1000 \\
\hline Pb (lead) & 200 & 1000 \\
\hline S (sulfur) & 250 & 1000 \\
\hline Si (silicon) & 200 & 200 \\
\hline Sm (samarium) & 2 & 1000 \\
\hline Sn (tin) & 100 & 2500 \\
\hline Ta (tantalum) & 200 & 500 \\
\hline Ti (titanium) & 100 & 2500 \\
\hline Th (thorium) & 100 & 100 \\
\hline V (vanadium) & 300 & 2500 \\
\hline W (tungsten) & 200 & 2500 \\
\hline Zn (zinc) & 150 & 1000 \\
\hline Zr (zirconium) & 50 & 1000 \\
\hline Total Impurities $^{\mathrm{d}}$ & 23,600 & \\
\hline
\end{tabular}

a "Maximum content" is the standard value that the feedstock shall meet during routine operations. 
b "Maximum exceptional content" is the maximum value for which the feed is acceptable as long as the total impurities value is not exceeded.

${ }^{\mathrm{c}} \mathrm{H}$-Area is not required to verify the nitrogen levels in the product. MOX Services will confirm the nitrogen limits are met with statistical sampling and analysis prior to dissolving. ${ }^{\mathrm{d}}$ Impurities that are not listed are assumed present at levels that do not affect MFFF safety, process, and product quality. 


\section{Distribution:}

S. D. Fink, 773-A

K. M. Fox, 999-W

B. J. Giddings, 786-5A

C. C. Herman, 999-W

S. L. Marra, 773-A

F. M. Pennebaker, 773-42A

W. R. Wilmarth, 773-A

E. A. Kyser, 773-A

T. S. Rudisill, 773-A

R. A. Pierce, 773-A

M. L. Crowder, 773-A

W. D. King, 773-42A

M. C. Thompson, 773-A

J. M. Duffey, 773-A

D. K. Veirs, LANL

J. M. Berg, LANL

R. R. Livingston, 730-2B

Records Administration (EDWS)
W. E. Harris, 704-2H

J. B. Schaade, 704-2H

G. J. Zachman, 225-7H

P.B. Andrews, 704-2H

S.J. Howell, 221-H

K. P. Burrows, 704-2H

K. J. Gallahue, 221-H

J. E. Therrell, 704-2H

J. W. Christopher, 704-2H

S. L. Garrison, 704-2H

W. G. Dyer, 704-2H

M. J. Swain, 703-H

M. J. Lewczyk, 221-H

R. H. Smith, 704-2H

K. D. Scaggs, 704-2H

S. L. Hudlow, 221-H

W. H. Clifton, 704-2H

A. T. Masterson, 704-2H

S. A. Thomas, 703-46A 